\title{
Convenience Voting Can Affect Election Outcomes
}

\author{
Marc Meredith and Neil Malhotra
}

\begin{abstract}
Forms of convenience voting, including voting-by-mail (VBM), provide citizens the opportunity to cast ballots without being exposed to the information revealed in the final weeks leading up to Election Day. This creates the possibility that informational differences will cause VBM and polling place voters to vote differently. We test this hypothesis by looking at whether the increased use of VBM at the precinct-level relates to candidates' vote shares in the 2008 California presidential primary. An election administration policy in California, in which all voters are assigned to VBM based on an arbitrary threshold of the number of registered voters, is exploited to overcome the identification problem caused by the selfselection of voters into VBM. We show that the use of VBM affects the relative performance of candidates remaining in the race and increases the probability of selecting withdrawn candidates. Our findings have implications both for election administration policy and for the study of campaign effects in American elections. Election officials should consider waiting until closer to Election Day to send out mail ballots, or instruct voters to wait until they are ready to make a decision before voting.
\end{abstract}

A GROWING SEGMENT of the United States electorate uses forms of voting that allow voters to cast ballots before Election Day. Political scientists refer to these non-polling place forms of voting as convenience voting, of which vote-bymail (VBM) and early in-person voting are the most common (see Gronke et al. (2008) for a summary of the literature on convenience voting). ${ }^{1}$ Thirty-four states allow voters to cast no-excuse VBM or early in-person ballots, and the remainder allow VBM if voters have certain excuses for why they cannot vote in person. ${ }^{2}$ In a number of these states convenience voters make up an increasingly substantial portion of the electorate; in California, for example, the percent of mail voters in the presidential primary increased from less than ten per-

Marc Meredith is an assistant professor in the Department of Political Science at the University of Pennsylvania. Neil Malhotra is an associate professor in the Graduate School of Business at Stanford University. cent in 1988 to $23.4,34.3$, and 41.7 percent in 2000, 2004, and 2008, respectively. ${ }^{3}$

Casting a ballot before Election Day also means casting a ballot before the campaign has concluded. This has raised numerous concerns among candidates, journalists, and campaign professionals. In an op-ed in the Wall Street Journal, Eliot Cutler, the unsuccessful independent candidate in the 2010 Maine gubernatorial election, recounts speaking to a woman on the campaign trail who, although intrigued by his policy positions, had already voted and exclaimed "Oh dear, I think I made a mistake!" Cutler writes: "early voting diminishes the already

\footnotetext{
${ }^{1}$ Some past work has referred to mandatory mail balloting as "vote-by-mail" and individuals selecting a mail ballot as "absentee voting." In this article we use the term "vote-by-mail" to refer jointly to both types of mail ballots.

${ }^{2}$ Retrieved from < http://www.earlyvoting.net/states/abs laws .php $>$ on Sept. 23, 2008.

${ }^{3}$ Retrieved from < http://www.sos.ca.gov/elections/hist absentee.htm $>$ on Sept. 23, 2008.
} 
scant attention voters pay to the issues in an election campaign. Election Day has become merely the end point in a drawn-out voting period dominated in its early stages by news media preoccupation with questionable polls and predictions" (Cutler 2010). Journalist Tom Curry notes that campaigns have been permanently altered by the expansion of convenience voting. As he puts it: "Move over Election Day, make way for Election Month." Democratic strategist Steve Schale concurs, noting that due to early voting: "Campaigns become more expensive, they become more front-loaded" (Curry 2008). A presumption underlying these concerns is that convenience voting affects election outcomes because some convenience voters' behavior would change if they voted after being exposed to the last portion of a campaign. However, this presumption has not been subject to empirical scrutiny.

There is significant heterogeneity across states in when VBM ballots are distributed; in Georgia ballots are distributed 45 days prior to Election Day compared to 15 days prior in Alaska. ${ }^{4}$ Distributing VBM ballots weeks before Election Day gives citizens flexibility in deciding when to vote. On the other hand, it also increases the window of time for new campaign information to be revealed after people have been given the opportunity to vote. This information could come in many forms: candidate withdrawals, election results in other states, debate performances, campaign advertisements, endorsements from newspapers and public figures, polls, and election coverage by the mass media. Many voters almost certainly will vote for a given candidate no matter what information is revealed in the final weeks of the campaign, but other voters' candidate choices could change as a result of information that may be revealed in the final days of the campaign. If such information is revealed after VBM ballots have been cast, the use of VBM may affect election outcomes.

This article explores the effects of use of VBM on candidate performance in the 2008 California presidential primary. We choose to study this specific election because a lot of information was revealed between when ballots were distributed and Election Day. Thus, it presents a good case for studying whether we observe patterns that are consistent with the use of VBM causing voters to fail to incorporate late campaign information. We examine how mail balloting affects two quantities: (1) the relative vote shares of candidates who remained in the race, and (2) the vote shares of candidates who withdrew from the race prior to Election Day.

Estimating whether the use of VBM affects election outcomes is complicated by the fact that people generally get to choose their method of voting. Some of the factors that affect voters' preferences for using different voting methods are likely to also affect their candidate preferences. For instance, previous research has generally shown that Election Day voters are younger, less educated, and less partisan-all factors that affect vote choice (Patterson and Caldeira 1985; Dubin and Kalsow 1996; Stein 1998; Baretto et al. 2006; Stein et al. 2004, though see Neeley and Richardson 2001 for an alternate account). This creates what social scientists often refer to as an "identification problem"-we cannot determine whether observed differences in the vote choices made by VBM and polling place voters represent the effect of VBM or instead the preferences of those who choose to use the different voting methods. Moreover, the assumptions needed for standard regression analysis to solve this identification problem are unlikely to be satisfied because some of the variables that jointly affect the use of VBM and determine candidate choice are likely to be unobservable.

The ideal method to isolate the effects of VBM is an experiment where some voters are randomly assigned to use VBM and others are randomly assigned to vote in a polling place. In this study, we leverage an election administration policy in California, previously identified by Kousser and Mullin (2007), which produces some variation in the use of VBM that approximates such an experiment. ${ }^{5}$ Briefly, the California Election Code permits county elections officials to require all voters to use VBM if a precinct contains 250 or fewer registered voters (hereafter, "VBM-only" precincts). ${ }^{6}$ This policy results in substantially different amounts of VBM use in two types of precincts - those with slightly more than 250 registered voters and those with slightly fewer than 250 registered voters-

\footnotetext{
${ }^{4}$ Georgia Code 21.2.384 and Alaska Code sec. 15.20.040 and sec. 15.20.045, respectively.

${ }^{5}$ Kousser and Mullin (2007) study the effects of mandated VBM on turnout.

${ }^{6}$ Because California often has several overlapping districtsand consequently a plethora of ballot forms-these small precincts are often in dense urban areas, along with more rural portions of the state.
} 
that do not result from selection. Our analysis leverages this discontinuous change in the use of VBM by testing how candidate performance differs in these two precinct types. Because absent the change in policy we would not expect to observe any systematic difference between precincts with just over 250 registered voters and just under 250 registered voters, we can attribute any differences in candidate performance we observe between the two types of precincts to difference in the use of VBM.

This research design produces two main results. First, the use of VBM affects the vote shares of candidates who remain in the race. Consistent with trends in prediction market and polling data as well as theories of momentum in sequential elections, we find that Hillary Clinton and Mike Huckabee performed relatively better among VBM voters. Our point estimates indicate that the difference between Clinton's and Barack Obama's vote shares was about ten percentage points larger on VBM ballots relative to polling place ballots. Given that roughly 40 percent of ballots were cast by mail in this race, this suggests that the presence of mail balloting increased the final difference between Clinton's and Obama's vote shares by four percentage points. Our point estimates also indicate that Huckabee outperformed John McCain and Mitt Romney by about four percentage points on VBM ballots relative to polling place ballots.

Second, we show that the use of VBM significantly increases the probability of supporting withdrawn candidates. We use the estimated effect sizes of the use of VBM on support for withdrawn candidates to approximate the percentage of supporters of withdrawn candidates who failed to incorporate information about their withdrawal into their VBM votes. Our point estimates suggest that 35 to 50 percent of John Edwards supporters and 15 to 35 percent of Rudy Giuliani supporters did not incorporate information about their withdrawals-which occurred six days prior to Election Day-on VBM ballots. Likewise, about 15 to 25 percent of Fred Thompson supporters did not incorporate information about his withdrawal-which occurred sixteen days prior to Election Day — on VBM ballots. Knowledge of these quantities is valuable in order to assess the implications of our results in other contexts where information is revealed late in the campaign.

Our results also have implications for the study of campaigns and elections. The finding that Clinton and Huckabee performed better among VBM voters is consistent with past work highlighting the importance of campaign dynamics in determining presidential primary election outcomes (e.g., Bartels 1988; Kenney and Rice 1994; Knight and Schiff 2010). Moreover, these findings suggest that voters underestimate the likelihood that their candidate preferences will shift. Our results also highlight a new method that can be broadly applied to study campaign effects. That is, if the selection process for VBM or early inperson voting can be modeled, researchers will be able to compare differences between convenience and polling place voters to study the effects of the campaign on election outcomes.

The article proceeds as follows. The first section details the 2008 California presidential primary. The following sections present our principal hypotheses, describe the discontinuity produced by Section 3003 of the California Election Code, and discuss the econometric methods to test them. The final two sections present the results and discuss their implications.

\section{THE 2008 CALIFORNIA PRESIDENTIAL PRIMARY}

California was one of the twenty-four states holding at least one primary or caucus on February 5, 2008. On the Democratic side, eight candidates appeared on the ballot-Mike Gravel, John Edwards, Joe Biden, Barack Obama, Chris Dodd, Hillary Clinton, Bill Richardson, and Dennis Kucinich-although only Obama, Clinton, and Gravel remained in the race through Election Day. Clinton edged Obama 51.5 to 43.2 percent, netting her approximately 55 percent of the state's Democratic convention delegates. On the Republican side, eleven candidates appeared on the ballot-Mike Huckabee, Duncan Hunter, Tom Tancredo, Fred Thompson, Rudy Giuliani, Sam Brownback, John Cox, John McCain, Mitt Romney, Ron Paul, and Alan Keyes-although only Huckabee, McCain, Romney, Paul, and Keyes remained in the race. McCain won the Republican race with 42.3 percent of the vote and nearly all of the available Republican convention delegates, with Romney and Huckabee finishing second and third with 34.6 and 11.7 percent of the vote, respectively.

Figure 1 provides a timeline of the important events leading up to the California primary. On November 6, 2007, 88 days before Election Day, 


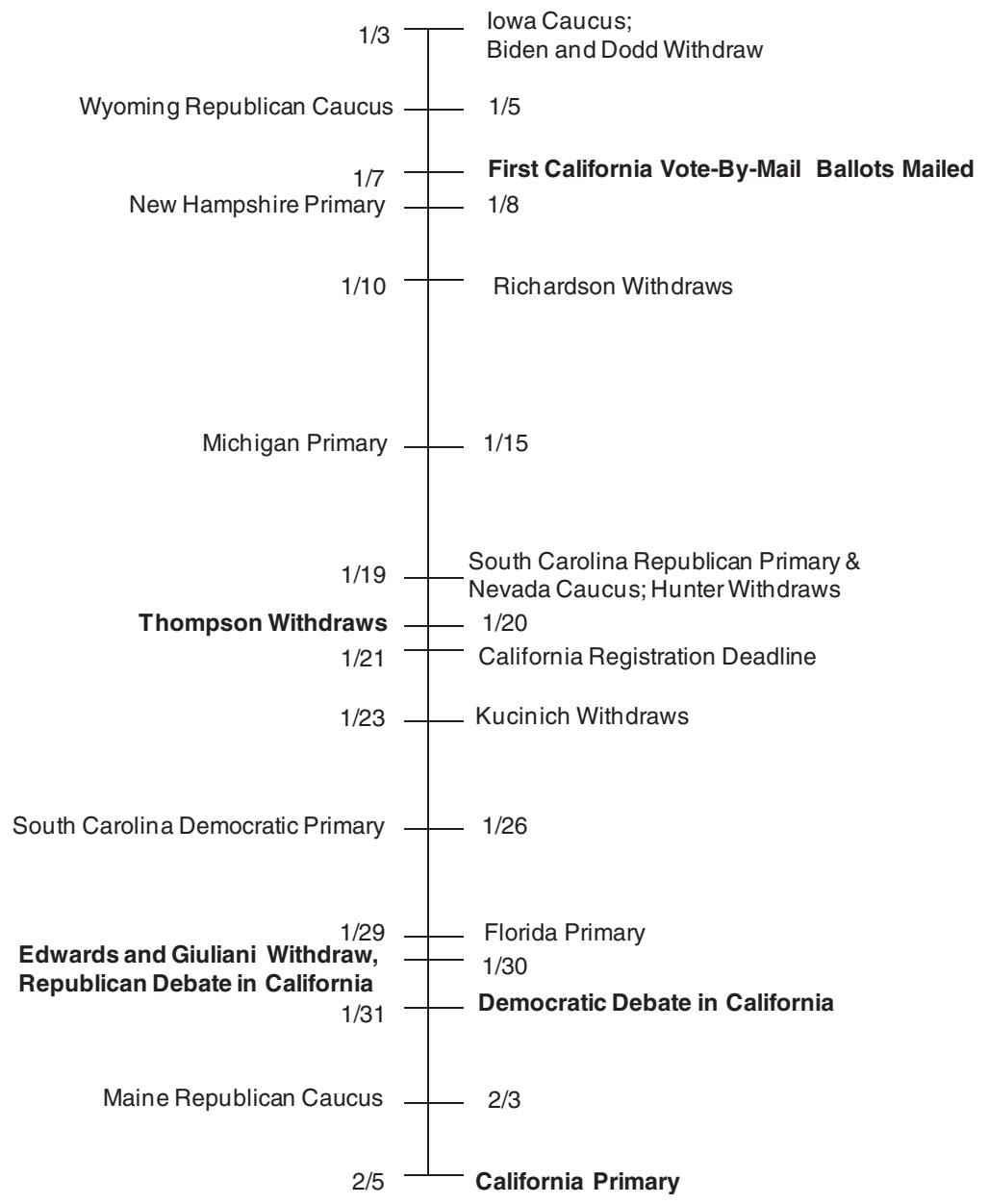

FIG. 1. Timeline of events.

the total number of voters registered in a precinct determined the precinct's eligibility for VBM-only status. The first votes in both the Democratic and Republican presidential nominating contests were cast in the Iowa caucuses on January 3, 2008. Four days later, one day before the New Hampshire primary, California counties began distributing VBM ballots to both registered voters choosing to voteby-mail and to all registered voters in mail-ballot only precincts. These VBM ballots required receipt by county officials by 8:00 P.M. PST on Election Day to be counted and could be returned either via mail or dropped off at any polling place in the county.

Figure 1 shows that a number of candidates withdrew from the race after the distribution of VBM ballots, but prior to Election Day. Fred Thompson withdrew from the Republican race on January 20, 2008, sixteen days prior to the California primary, after finishing third with about 16 percent of the vote in the South Carolina primary. Rudy Giuliani followed suit on January 30, 2008 after finishing third in the Florida primary with about 15 percent of the vote. John Edwards dropped out of the Democratic race on the same day after finishing third with eighteen and fourteen percent of the vote in South Carolina and Florida, respectively.

The relative positions of candidates remaining in the race also changed considerably after the distribution of VBM ballots, but prior to Election Day. The top panel of Figure A1 in Appendix B illustrates the difference in the percentage of Californians expressing support for Obama and Clinton over time, as measured by polls conducted in the state in the month prior to Election Day. The upward sloping black trend line indicates that the percentage of voters supporting Obama relative to Clinton increased between the distribution of VBM ballots and Election Day. The trend lines in the middle and bottom panels of Figure A1 show that Huckabee lost support relative to McCain and Romney, and 
that Romney gained support relative to McCain over this same time period.

We find similar patterns when examining prediction markets data. The top panel of Figure A2 in Appendix B shows how the prices of contracts from Intrade paying $\$ 1$ if Hillary Clinton and Barack Obama won the Democratic nomination varied over this time period. The Clinton contract appreciated following her $51 \%-45 \%$ victory in the Nevada caucuses, but returned close to its previous level following her larger-than-expected 55\%-27\% loss to Obama in the South Carolina primary. The bottom panel of Figure A2 shows how the prices of similar contracts paying \$1 if John McCain, Mitt Romney, and Mike Huckabee won the Republican nomination varied over the same time period. McCain's victories in the South Carolina and Florida primaries substantially increased the value of his contract, while Romney's victories in the Michigan primary and the Nevada caucuses left him as the only other candidate with a non-trivial chance of winning the Republican nomination. Huckabee's contract dropped from about $\$ 0.17$ when VBM ballots were distributed to less than $\$ 0.01$ on Election Day after he failed to win any primary or caucus in this time span after his initial victory in Iowa.

\section{HYPOTHESES}

We expect that the revelation of campaign information after the distribution of mail ballots will cause candidate performance to differ between VBM and polling place voters, net of the types of voters who select into the different forms of voting. There are a number of reasons to expect this phenomenon. A well-established literature in behavioral economics shows that people tend to be overconfident in decision making (e.g., Svenson 1981; Camerer and Lovallo 1999) and that overconfidence can affect behavior and judgment (e.g., Barber and Odean 2001; Daniel et al. 1998). As a result, voters will underestimate the likelihood that they will want to switch their votes prior to Election Day. Moreover, to the extent voting provides consumptive rather than investment benefits, individuals may choose to consume the act of voting as soon as possible (Fiorina 1976), even at the risk of not voting for the candidate they ultimately prefer. Finally, some voters may be more risk-averse about casting a ballot than ensuring they choose their preferred candidate.

These effects may be particularly prevalant in primary elections, where late-breaking information is more likely to affect vote choice. Unlike general elections, voters often cannot rely on longstanding attachments and information that is known well before ballots are mailed out. For instance, while partisanship (Campbell et al. 1960) and issue positions (Carmines and Stimson 1980) strongly affect vote choices in general elections, in primaries party labels are constant and candidates often take similar stances on public policy questions. Moreover, contested primaries often do not feature incumbents, meaning that citizens cannot retrospectively evaluate government performance (Fiorina 1981). We would expect less of an effect in general elections because strong partisans are more likely than Independents to vote early (Stein et al. 2004), and these voters tend to be more resistant to campaign effects (Fournier et al. 2004).

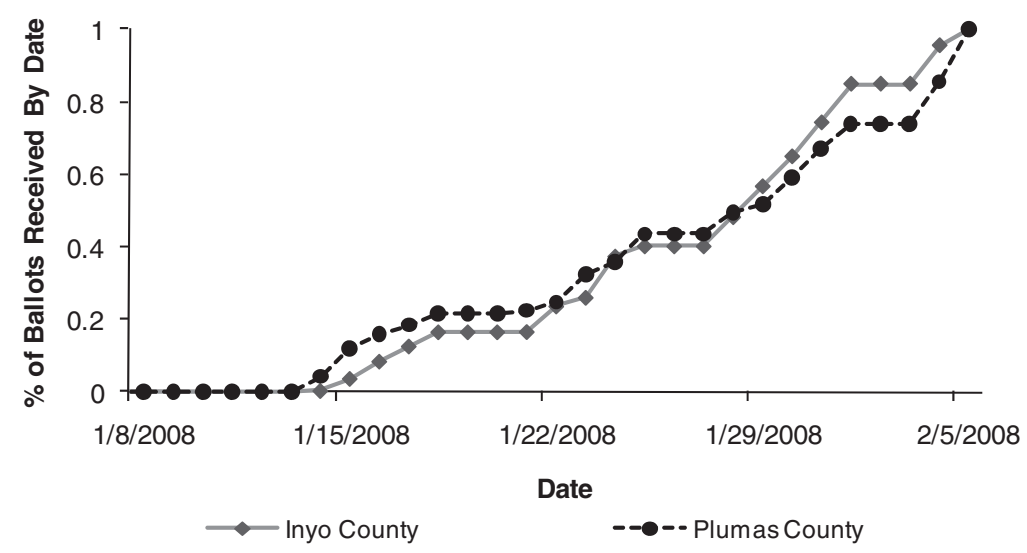

FIG. 2. Distribution of ballot receipt date in the 2008 California presidential primary. 
Figure 2 presents the distribution of the date of receipt of VBM ballots in Inyo County and Plumas County for the 2008 California presidential primary. ${ }^{7}$ The figure shows that in both counties over half of the VBM ballots were returned more than seven days prior to Election Day. Given all of the information that was revealed in the final weeks of the campaign, some of the VBM voters who returned their ballots prior to February 5th may have voted differently on Election Day. On the other hand, those voters who returned their VBM ballots long before Election Day may have been committed to supporting specific candidates in spite of almost any information revealed in the final weeks of the campaign. ${ }^{8}$ For example, some supporters continue to support their preferred candidates after they have withdrawn from the race. ${ }^{9}$ If most ballots returned early are from such voters, then convenience voting will not affect election outcomes.

We first estimate the effect of VBM on the relative performance of candidates remaining in the race. We expect that the increased support for Obama leading up to Election Day will cause VBM voters to be less likely to support Obama relative to Clinton than polling place voters. Similarly, we predict that VBM voters will be more likely to support Huckabee relative to McCain or Romney than polling place voters. ${ }^{10}$ The predicted effect of VBM on support for Romney relative to McCain is ambiguous given different trends observed in the polling and prediction market data in Figure A1 and Figure A2 in Appendix B.

We also investigate whether VBM affects the vote shares of the major candidates that withdrew from the race in the interval between the distribution of ballots and the primary. We predict that VBM voters will be more likely to cast ballots for Edwards, Giuliani, and Thompson. Although the hypothesis that people will be less likely to vote for withdrawn candidates may seem obvious, we conduct this analysis for two reasons. First, these results provide a baseline to show the efficacy of our method. Second, we can use the estimated effect sizes to approximate the percentage of supporters of withdrawn candidates who failed to incorporate information about the candidates' withdrawal into their VBM votes. Knowledge of this quantity is valuable in order to assess the implications of our results in other contexts where information is revealed in the final weeks of the campaign. Further, quantifying the percentage of voters who failed to incorporate information about withdrawals into their votes is informative for lawmakers and election administrators when assessing the efficacy of different convenience voting methods.

\section{DESCRIPTION OF THE DATA GENERATING PROCESS}

Data

Our analysis uses precinct-level election returns from the 2008 February presidential primary for 40 of the 58 counties in California. ${ }^{11}$ We supplement our precinct-level vote totals with demographic data constructed by aggregating individual voting records from the California Statewide Voter File and census block demographic data to the consolidated precinct level, the precincts from which VBM-only status is assigned and election results are reported. Using correspondences obtained from either the Berkeley Statewide Voter Database or directly from the counties, we map individuals' voter file records to the consolidated precincts to construct precinct-level measures of age, gender, length of registration, and partisan identification. Using additional correspondences obtained from the Berkeley Statewide Voter Database, we aggregate census block data to the consolidated precincts to construct measures of the percent rural, white,

${ }^{7}$ Unfortunately, similar data for the 2008 California presidential primary are not available for most other counties. Similar data are available for elections in other states at $<$ http://www.earlyvoting.net/blog/ >

${ }^{8}$ An elections official in Colusa County illustrated this point in an interview. She observed that the return of ballots tended to be bi-modal, with one peak occurring immediately after the distribution of ballots, and the other peak just before the election. Her belief from conversations with voters was that ballots cast immediately after the distribution of ballots were from voters with more certain candidate preferences than ballots cast just prior to the election.

${ }^{9}$ Edwards and Huckabee received more than seven and ten percent of the vote in the West Virginia primary on May 13, 2008, respectively, months after each withdrew from the race.

${ }^{10}$ This may occur both because of strategic voting considerations (Abramson et al. 1992) and changes in perceptions of the relative quality of Huckabee, McCain, and Romney (Mutz 1999).

${ }^{11}$ We were unable to obtain a breakdown of the percentage of VBM and polling place ballots at the precinct-level in Orange, San Mateo, and Tuolumne counties. In these counties we impute the county average percentage of VBM ballots cast by mail in all traditional precincts, and we impute that $100 \%$ of ballots cast by mail in VBM-only precincts are VBM. We justify this imputation in the technical appendix (Appendix A). 
black, Asian, and Hispanic. ${ }^{12}$ We drop precincts from our analysis for which we are unable to match any registrants from the voter file or populated census blocks.

\section{Identification strategy}

The difficulty with studying the effects of the use of VBM on election outcomes is that it is difficult to construct comparable groups of individuals using VBM and polling place voting. In most states, individuals choose to use VBM or vote at the polling place. Therefore, a comparison of VBM and polling place outcomes is likely to confound the effects of VBM with selection. Conversely, if VBM is mandatory, comparisons are made by looking within states across time (e.g., comparing Oregon before and after mandatory VBM) or within time across states (e.g., comparing Oregon and Washington). While such analyses reduce selection concerns, differences in the political environment and the characteristics of the electorate between $t$ and $t+1$ or across states are potential confounds.

Our analysis exploits an election administration policy in California that results in a small subset of the state being forced to use VBM, while the remainder of the state is allowed to choose between VBM and polling place voting. Section 3003 of the California Election Code specifies that counties can declare that a precinct is VBM-only if 88 days prior to an election there are fewer than 250 registrants. ${ }^{13}$ A precinct is a geographic grouping of registered voters that consists of no more than 1,000 voters that use the same ballot form. ${ }^{14}$ In contrast to a "traditional precinct" where individuals can choose between using VBM and polling place voting, everyone in a VBM-only precinct is required to use VBM. ${ }^{15}$ Our final data sample includes 2,507 VBM-only and 14,352 traditional precincts.

In practice, the determination of VBM-only precincts is slightly more complicated than suggested by Section 3003. We observe a substantial number of VBM-only precincts with more than 250 registrants on Election Day. In order to determine the source of these discrepancies, we interviewed election officials from most of the counties in our dataset. The election officials provided us with a number of reasons why we would observe VBM-only precincts with more than 250 registrants. First, the statement of the vote reports the number of registrants on Election Day, while VBM-only status was determined based on the number of registrants on approximately November 6,2007 . Second, a number of counties told us that they excluded permanent absentee voters when determining whether a precinct was eligible to be VBM-only. The logic here is that including permanent VBM voters would be "double counting" because they are not expected to visit the polling place on Election Day. Other counties told us that results were reported at a different level of aggregation than what is used to determine VBM-only status. We drop all but one county that excluded absentee voters or reported results at a different level of aggregation than what was used to determine VBM-only status. ${ }^{16}$ Finally, multiple county elections officials cited the non-availability of a suitable polling place location as a reason for making a precinct with more than 250-registrants VBM-only. For example, a county official told us that a precinct with more than 250 registrants was VBM-only because a highway divided a precinct into two parts. Multiple counties made military bases VBM-only regardless of the registration due to security concerns.

Comparing election outcomes in these VBMonly and traditional precincts alleviates a number of the concerns discussed above about naively comparing VBM and polling place voters. Individuals who would otherwise choose to vote at traditional polling places are forced to use VBM in VBM-only precincts, creating differences in the level of VBM

\footnotetext{
${ }^{12}$ Because precinct boundaries are independent of census block boundaries, some census blocks are contained in multiple precincts. In such cases we allocate demographics to precincts as a percentage of the census block population contained in each precinct. For example, if a precinct is 60 percent in census block $\mathrm{A}$ and 40 percent in census block $\mathrm{B}$, we assign it a weighted average of .6 of census block A's characteristics and .4 of census block B's characteristics.

${ }^{13}$ Section 3003 also states that precincts are not allowed to be divided in order to conform to the 250 registrant requirement.

${ }^{14}$ Because of new registrants entering existing precincts after boundaries are drawn, there are more than 1,000 registrants in some precincts.

${ }^{15}$ Voters in VBM-only precincts have the option of dropping their state-issued VBM ballot at a traditional polling place on Election Day. However, given that these polling places are located further from VBM-only voters' normal polling locations, the additional costs of locating and travelling to the nearest polling place to engage in in-person voting likely encourages many voters in VBM-only precincts to mail their ballots prior to Election Day (see Brady and McNulty 2011).

${ }^{16}$ The one exception is Santa Clara County, which provided us with a copy of exact counts of excluded absentee voters by precinct. Table A1 in Appendix B lists reasons we drop each excluded county.
} 
voting that is not generated by selection. Moreover, we compare voters facing the same political environment. Of course, because we are using aggregatelevel data, we have no way of measuring when an individual voter cast his or her ballot. Thus, we cannot make definitive claims about the mechanisms underlying any observed differences in vote choice. However, observing substantial and significant differences between VBM-only and traditional precincts in our hypothesized directions are highly suggestive of our proposed individual-level mechanisms.

Because precincts with a small number of registrants are not randomly selected from the universe of precincts, we are still concerned that the underlying characteristics of the electorate are different in VBM-only and traditional precincts. In the next section we develop two estimation techniques to account for the differences in the types of voters in VBM-only and traditional precincts.

\section{DESCRIPTION OF THE EMPIRICAL APPROACHES}

We use two different empirical approaches to account for differences in the types of voters in VBM-only and traditional precincts. The first approach follows Kousser and Mullin (2007) and uses the full set of precincts but preprocesses the data using Mahalanobis distance matching (Ho et al. 2007). The second approach, which is based upon a regression discontinuity design (RDD), compares the outcomes we observe in precincts that are just above the 250-registrant threshold with outcomes we observe in precincts that are just below the 250registrant threshold. We provide a brief description of each approach here, and provide greater details in a technical appendix (Appendix A).

\section{Matching approach}

The matching approach seeks to estimate the effects of the use of VBM by comparing similar VBM-only and traditional precincts. However as Column (1) of Table A2 in Appendix B illustrates, there are a number of differences in the characteristics of VBM-only and traditional precincts besides just the use of VBM. VBM-only precincts are more rural, contain fewer minorities, and have older and more Republican registrants than traditional precincts. As a result, we do not know the extent to which observed differences in candidate perfor- mance between VBM-only and traditional precincts are caused by the greater use of VBM, or instead by some other characteristics that systematically differ across these two types of precincts.

The matching approach seeks to find a set of traditional precincts that has the most similar set of voter file and census block characteristics as our VBM-only precincts. The procedure matches each VBM-only precinct to a traditional precinct that is the most similar according to some criterion. A second criterion assesses whether the resulting match is sufficiently similar, and discards those that are not similar enough. The VBM-only and traditional precincts that remain in the dataset after going through this matching should be nearly identical on all of the variables on which we matched. Thus, if we match on all of the variables that jointly affect determination of VBM-only status and candidate choice, any systematic differences we observe in the vote shares of candidates in VBM-only and traditional precincts can be attributed to VBM.

We find that our matching procedure generates a set of VBM-only and traditional precincts that looks nearly observably identical except in their use of VBM. Column (2) of Table A2 illustrates the differences in the observable characteristics of VBM-only and traditional precincts when we compare all VBM-only precincts to their most closely matched traditional precinct. While we find substantively small and statistically insignificant differences on most of the matched variables, VBM-only precincts are still substantively more rural. Differences in the percentage of registrants between the ages of 30 and 44 and the percentage of registrants who registered after November 6, 2007 ("late registrants") are also statistically significant at the 95-percent level. Column (3) shows these differences largely vanish when we drop matches that are not sufficiently close. Moreover, on none of the observable variables do we observe a significant difference at the $p<.10$ level between VBM-only and traditional precincts. The similarity of all eighteen voter characteristic variables bolsters our claim that differences in the voting outcomes observed between VBM-only and traditional precincts in the next section are not caused by differences in the types of voters, but rather by the voting method per se.

\section{RDD-based approach}

First proposed by Thistlethwaite and Campbell (1960), regression discontinuity designs (RDDs) 


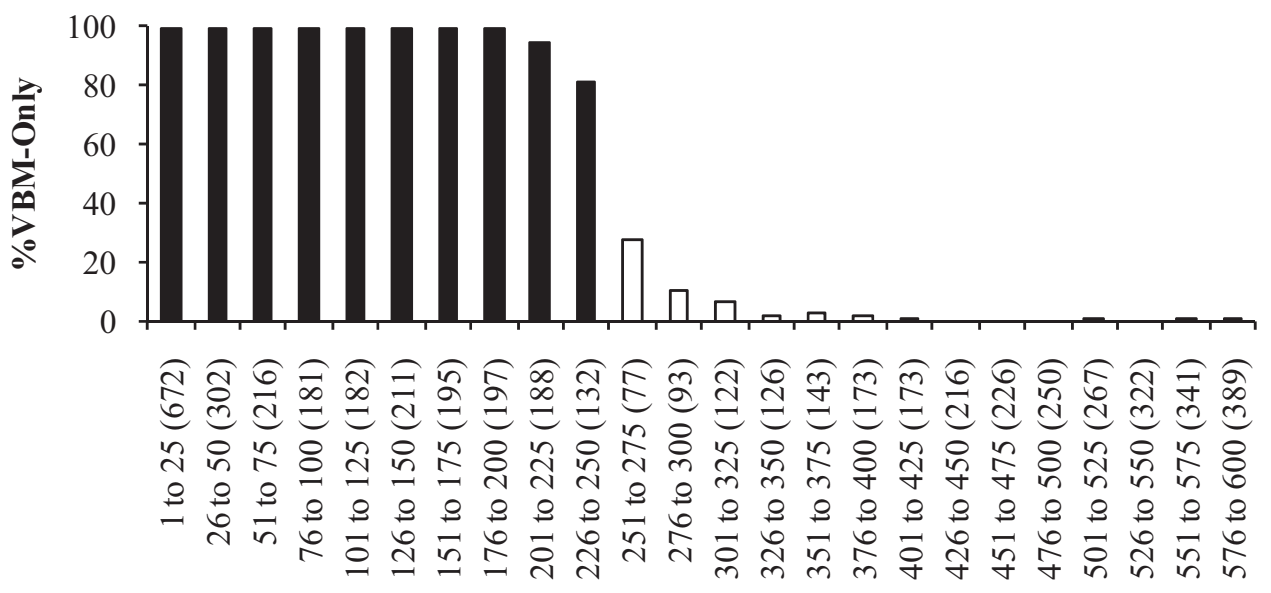

Approximate Number of Registered Voters on 11/6/2007 (\# of obs.)

FIG. 3. Illustration of 250-registrant discontinuity.

have recently reemerged as one of the primary tools for performing causal analysis in the social sciences. An RDD is potentially feasible when the value of a continuous variable discontinuously affects the assignment of treatment. The original application used by Thistlethwaite and Campbell was a scholarship that was given to students who scored above a threshold on a standardized test. To see if the scholarship affected students' career prospects, they calculated differences in the career aspirations of students who scored just above the threshold and students who scored just below the threshold. Because students who score just above and below the cutoff are likely to be similar on a host of traits, including intelligence and diligence. Subsequent work discusses how this causal claim is strengthened when pre-treatment and placebo outcomes that should not be affected by the treatment exhibit no differences around the threshold (Imbens and Lemieux 2008).

We take a similar approach to assess whether the use of VBM affects candidate choice in the 2008 California presidential primary. Just as in Thistlethwaite and Campbell, VBM-only status is a treatment that is assigned on the basis of whether a variable, the number of registrants in the precinct on November 6, 2007, is above a threshold. Therefore, to assess whether the use of VBM affects candidate choice, we test whether candidate vote shares are systematically different in precincts with just over 250 registrants compared to precincts with just under 250 registrants.
Because having just over 250 registrants (as compared to having just below 250 registrants) should not affect candidate choice if not for Section 3003 of the California Election Code, we interpret any difference we observe in candidate vote shares as the causal effect of the use of VBM. To bolster this claim, we also show that there are no observable systematic differences in the composition of voters between the two types of precincts.

In practice, the analysis we describe above is complicated by the fact that we only can approximate the number of registered voters in each precinct on November 6, 2007 (hereafter, "approximate registrants"), the date on which VBM-only status was established. While Figure 3 illustrates that having fewer than 250 approximate registrants substantially increases the probability of a precinct being VBM-only, it also suggests that our approximation likely causes some misclassification of whether there were fewer than 250 registrants in precincts that had almost exactly 250 registrants. As we discuss in the technical appendix (Appendix A), this form of misclassification makes it difficult to implement some of the RDD best practices established by Imbens and Lemieux (2008). Moreover, Table A3 in Appendix B shows there are some observable differences in the composition of voters in precincts that have just more and just less than 250 approximate registrants. To overcome these problems, we adopt a method that compares precincts with around 250 approximate 
Table 1. Estimates of Vote-By-Mail on Vote Shares in the Democratic Primary

(STANDARD ERRORS IN PARENTHESIS)

\begin{tabular}{|c|c|c|c|c|c|c|c|c|}
\hline \multicolumn{5}{|c|}{ Matching Estimator } & \multicolumn{4}{|c|}{ RDD-Based Estimator } \\
\hline Sample: & $\begin{array}{c}(1) \\
\text { Full }(O L S)\end{array}$ & $\begin{array}{c}(2) \\
\text { Full }(I V)\end{array}$ & $\begin{array}{c}\text { (3) } \\
\text { Matched }\end{array}$ & Caliper Matched & Bandwidth $(b)$ : & $\begin{array}{c}(5) \\
50\end{array}$ & $\begin{array}{l}(6) \\
75\end{array}$ & $\begin{array}{l}(7) \\
100\end{array}$ \\
\hline Observations & 16,724 & 16,724 & 3,904 & 1,296 & $251-\mathrm{b} \leq$ Registrants $\leq 250$ & 271 & 456 & 633 \\
\hline Mail Precincts & & 2,372 & 2,372 & 707 & $251-\mathrm{b} \leq$ Registrants $\leq 250$ & 157 & 262 & 369 \\
\hline $\begin{array}{l}\text { Traditional } \\
\text { Precincts }\end{array}$ & - & 14,352 & 1,532 & 589 & $250+\mathrm{b}<$ Registrants & 1,019 & 1,485 & 1,863 \\
\hline $\begin{array}{l}\text { First Stage } \\
\% \text { Mail Ballots }\end{array}$ & - & $\begin{array}{c}0.532 \\
(0.004)\end{array}$ & $\begin{array}{c}0.521 \\
(0.006)\end{array}$ & $\begin{array}{c}0.511 \\
(0.007)\end{array}$ & $\begin{array}{l}\text { First Stage } \\
\% \text { Mail Ballots }\end{array}$ & $\begin{array}{c}0.293 \\
(0.016)\end{array}$ & $\begin{array}{c}0.346 \\
(0.012)\end{array}$ & $\begin{array}{c}0.381 \\
(0.010)\end{array}$ \\
\hline $\begin{array}{l}\text { Second Stage } \\
\% \text { Obama - } \\
\% \text { Clinton }\end{array}$ & $\begin{array}{l}-0.096 \\
(0.020)\end{array}$ & $\begin{array}{l}-0.084 \\
(0.028)\end{array}$ & $\begin{array}{l}-0.102 \\
(0.022)\end{array}$ & $\begin{array}{c}-0.086 \\
(0.032)\end{array}$ & $\begin{array}{c}\text { Second Stage } \\
\% \text { Obama - } \\
\% \text { Clinton }\end{array}$ & $\begin{array}{l}-0.165 \\
(0.063)\end{array}$ & $\begin{array}{l}-0.117 \\
(0.041)\end{array}$ & $\begin{array}{l}-0.108 \\
(0.031)\end{array}$ \\
\hline$\%$ Edwards & $\begin{array}{c}0.081 \\
(0.002)\end{array}$ & $\begin{array}{c}0.047 \\
(0.002)\end{array}$ & $\begin{array}{c}0.039 \\
(0.003)\end{array}$ & $\begin{array}{c}0.038 \\
(0.005)\end{array}$ & $\%$ Edwards & $\begin{array}{c}0.041 \\
(0.011)\end{array}$ & $\begin{array}{c}0.039 \\
(0.007)\end{array}$ & $\begin{array}{c}0.045 \\
(0.006)\end{array}$ \\
\hline
\end{tabular}

registrants to geographically proximate precincts well above the 250-registrant threshold (see technical appendix for exact details). The idea is that we can use the geographically proximate precincts with substantially more than the 250registrant threshold to estimate the counterfactual difference in outcomes in precincts just above and below the 250-registrant threshold if there was no difference in the use of mail balloting.

Table A4 in Appendix B shows that while having more than 250 approximate registrants substantially decreases the use of VBM, it is not significantly related to most other voter characteristics that might affect candidate choice. We define $b$ as a bandwidth parameter from which we set the bounds on how close the number of approximate registrants has to be to 250 in order to be included in the analysis (e.g., compare precincts with between $251-b$ and 250 approximate registrants to precincts with between 251 and $250+b$ approximate registrants). Table A4 shows that for $b=\{50,75,100\}$, the differences we observe in voter characteristics in precincts with just over 250 approximate registrants and just under 250 approximate registrants is generally substantively small, and on only a small number of variables statistically significant. Figure A3 in Appendix $\mathrm{B}$ shows that this balance is not unique to the chosen bandwidths of $b$, although balance does appear to get slightly worse as $b$ becomes larger. The substantively small and statistically insignificant differences in voter characteristics suggests that the effects of VBM identified in the next section using our RDD-based approach are not caused by differences in the types of voters (see Dunning 2008).

\section{Comparing the approaches}

The matching and RDD-based approaches each have comparative advantages and disadvantages. Matching generates a set of VBM-only and traditional precincts that share nearly identical voter file and census block characteristics. By incorporating a higher percentage of the VBM-only observations into the analysis, the matching approach also has greater statistical power. The weakness is that while this matching assures balance on the observables, matching may not produce unbiased estimates if all factors that jointly affect VBMonly status and candidate choices are not matched upon (Arceneaux et al. 2006). This may be particularly problematic if counties are determining VBM-only status based on variables like the number of permanent absentees, which are both generally unobserved and potentially related to political preferences. $^{17}$

In comparison, the RDD-based approach uses the treatment assignment implied by the California Election Code, rather than actual VBM-only status, as its primary identifying variation. As a result, it is less susceptible to selection bias if county officials

\footnotetext{
${ }^{17}$ For example, Butte, El Dorado, Napa, and Riverside are included in Kousser and Mullin's (2007) sample, but the percent of permanent absentee voters is not one of the matched variables.
} 

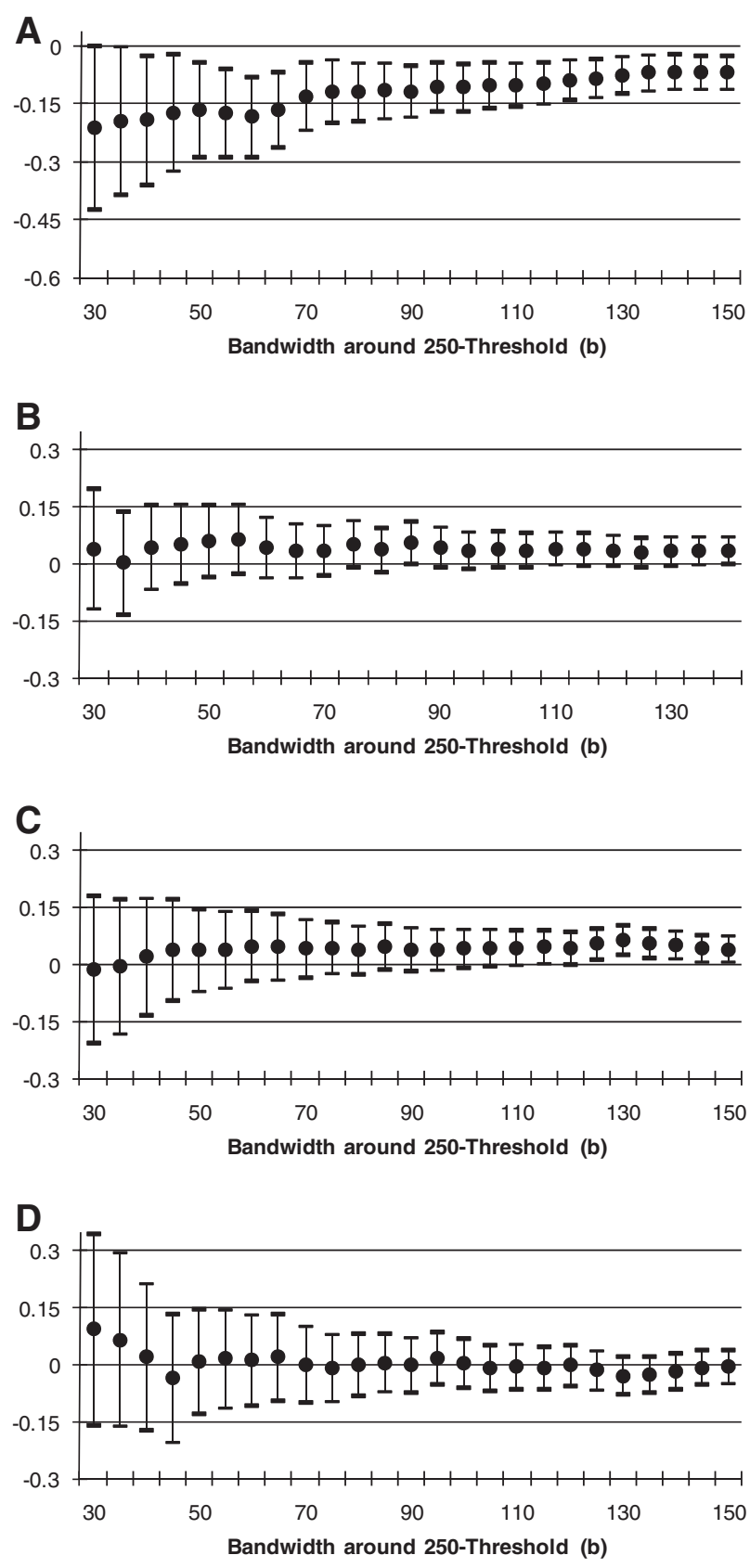

FIG. 4. Effects of VBM on support for remaining candidates. Circles indicate point estimates, bars indicate $95 \%$ confidence interval. (A) Effect of VBM on Obama's minus Clinton's vote share. (B) Effect of VBM on Huckabee's minus McCain's vote share. (C) Effect of VBM on Huckabee's minus Romney's vote share. (D) Effect of VBM of Romney's minus McCain's vote share.

select certain types of precincts to be VBM-only. It also compares precincts of relatively similar sizes and controls for geography at a finer level. The cost of such of an approach is that we do not achieve as precise a balance on the other observables and we have less statistical power. Finding similar results across the two approaches assuages concerns about each approach individually.

\section{RESULTS}

We find that Barack Obama performed worse relative to Hillary Clinton among VBM voters. We first use the matching approach to examine how VBM affected the relative vote shares of Obama and Clinton in the Democratic primary (see Table 1). The naïve ordinary least squares (OLS) specification in column (1) shows a large correlation between the relative performance of Obama and the usage of VBM. The point estimate of -0.096 suggests that a one percentage point increase in the percentage of mail ballots is associated with a 0.096 percentage point decrease in Obama's vote share relative to Clinton's vote share. We continue to observe a significant negative relationship when we instrument for percentage of mail ballots with VBM-only status. The first row of coefficients indicates that being a VBM-only precinct has significant first-stage explanatory power over the percentage of VBM ballots; in the caliper-matched sample VBM-only precincts cast 53.2 percentage points (s.e. $=0.4$ percentage points) more ballots by mail. Using this difference in mail ballots in VBM-only and traditional precincts as an instrument, we obtain a point estimate in the calipermatched sample that indicates that a one percentage point increase in the use of VBM causes an 0.086 percentage point (s.e. $=.032$ percentage points) reduction in the difference between Obama's and Clinton's vote shares.

Similar results are found using the RDD-based approach in columns (5)-(7) of Table 1. Even with a narrow bandwidth of 50, we find a large firststage increase of 29.3 percentage points in the percentage of mail ballots (s.e. $=1.6$ percentage points) when the approximate number of registrants is less than 250. Using this same bandwidth we find that a one percentage point increase in the use of VBM causes a 0.165 percentage point (s.e. $=0.063$ percentage points) reduction in the difference between Obama's and Clinton's vote shares. Figure 4A illustrates the robustness of this result to alternative bandwidths. Each black dot illustrates the point estimate for a given bandwidth, with the horizontal black lines showing the upper and lower bound of the corresponding 95\% percent confidence interval. We 
Table 2. Estimates of Vote-By-Mail on Vote Shares in the Republican Primary

(STANDARD ERRORS IN PARENTHESIS)

\begin{tabular}{|c|c|c|c|c|c|c|c|c|}
\hline \multicolumn{5}{|c|}{ Matching Estimator } & \multicolumn{4}{|c|}{ RDD-Based Estimator } \\
\hline Sample: & $\begin{array}{c}(1) \\
\text { Full }(O L S)\end{array}$ & $\begin{array}{c}(2) \\
\text { Full (IV) }\end{array}$ & $\begin{array}{c}(3) \\
\text { Matched }\end{array}$ & Caliper Matched & Bandwidth $(b)$ : & $\begin{array}{l}(5) \\
50\end{array}$ & $\begin{array}{l}(6) \\
75\end{array}$ & $\begin{array}{l}(7) \\
100\end{array}$ \\
\hline Observations & 16,693 & 16,693 & 3,851 & 1,288 & $251-\mathrm{b} \leq$ Approx. Reg. $\leq 250$ & 271 & 456 & 632 \\
\hline Mail Precincts & & 2,344 & 2,344 & 703 & $251 \leq$ Approx. Reg. $\leq 250+$ b & 157 & 262 & 368 \\
\hline $\begin{array}{l}\text { Traditional } \\
\text { Precincts }\end{array}$ & & 14,349 & 1,507 & 585 & $251+\mathrm{b}<$ Approx. Reg. & 1,019 & 1,485 & 1,858 \\
\hline $\begin{array}{l}\text { First Stage } \\
\% \text { Mail Ballots }\end{array}$ & $\longrightarrow$ & $\begin{array}{c}0.454 \\
(0.004)\end{array}$ & $\begin{array}{c}0.445 \\
(0.006)\end{array}$ & $\begin{array}{c}0.439 \\
(0.006)\end{array}$ & $\begin{array}{l}\text { First Stage } \\
\% \text { Mail Ballots }\end{array}$ & $\begin{array}{c}0.225 \\
(0.016)\end{array}$ & $\begin{array}{c}0.271 \\
(0.012)\end{array}$ & $\begin{array}{c}0.309 \\
(0.010)\end{array}$ \\
\hline $\begin{array}{l}\text { Second Stage } \\
\% \text { Huckabee - } \\
\text { \% McCain }\end{array}$ & $\begin{array}{c}-0.123 \\
(0.007)\end{array}$ & $\begin{array}{c}0.027 \\
(0.010)\end{array}$ & $\begin{array}{c}0.025 \\
(0.015)\end{array}$ & $\begin{array}{c}0.028 \\
(0.020)\end{array}$ & $\begin{array}{c}\text { Second Stage } \\
\% \text { Huckabee - } \\
\% \text { McCain }\end{array}$ & $\begin{array}{c}0.044 \\
(0.057)\end{array}$ & $\begin{array}{c}0.034 \\
(0.036)\end{array}$ & $\begin{array}{c}0.043 \\
(0.027)\end{array}$ \\
\hline $\begin{array}{c}\text { \% Huckabee - } \\
\text { \% Romney }\end{array}$ & $\begin{array}{c}-0.068 \\
(0.007)\end{array}$ & $\begin{array}{c}0.041 \\
(0.010)\end{array}$ & $\begin{array}{c}0.061 \\
(0.013)\end{array}$ & $\begin{array}{c}0.058 \\
(0.018)\end{array}$ & $\begin{array}{c}\text { \% Huckabee - } \\
\text { \% Romney }\end{array}$ & $\begin{array}{c}0.036 \\
(0.055)\end{array}$ & $\begin{array}{c}0.044 \\
(0.035)\end{array}$ & $\begin{array}{c}0.041 \\
(0.026)\end{array}$ \\
\hline $\begin{array}{l}\text { \% Romney - } \\
\text { \% McCain }\end{array}$ & $\begin{array}{c}-0.055 \\
(0.009)\end{array}$ & $\begin{array}{c}-0.014 \\
(0.012)\end{array}$ & $\begin{array}{l}-0.036 \\
(0.019)\end{array}$ & $\begin{array}{c}-0.031 \\
(0.026)\end{array}$ & $\begin{array}{l}\text { \% Romney - } \\
\text { \% McCain }\end{array}$ & $\begin{array}{c}0.008 \\
(0.071)\end{array}$ & $\begin{array}{l}-0.010 \\
(0.045)\end{array}$ & $\begin{array}{c}0.003 \\
(0.033)\end{array}$ \\
\hline$\%$ Giuliani & $\begin{array}{c}0.047 \\
(0.002)\end{array}$ & $\begin{array}{c}0.033 \\
(0.002)\end{array}$ & $\begin{array}{c}0.034 \\
(0.004)\end{array}$ & $\begin{array}{c}0.032 \\
(0.005)\end{array}$ & $\%$ Giuliani & $\begin{array}{c}0.015 \\
(0.015)\end{array}$ & $\begin{array}{c}0.018 \\
(0.010)\end{array}$ & $\begin{array}{c}0.029 \\
(0.007)\end{array}$ \\
\hline$\%$ Thompson & $\begin{array}{c}0.018 \\
(0.001)\end{array}$ & $\begin{array}{c}0.026 \\
(0.002)\end{array}$ & $\begin{array}{c}0.024 \\
(0.003)\end{array}$ & $\begin{array}{c}0.025 \\
(0.004)\end{array}$ & $\%$ Thompson & $\begin{array}{c}0.011 \\
(0.011)\end{array}$ & $\begin{array}{c}0.019 \\
(0.007)\end{array}$ & $\begin{array}{c}0.019 \\
(0.005)\end{array}$ \\
\hline
\end{tabular}

observe that the point estimates generally decrease as the bandwidth increases (i.e., as $b$ gets larger), but the effect of VBM remains significant at the 5\% level (i.e., the upper black line is consistently below zero).

There are a number of potential explanations for the negative effect of VBM on Obama's performance. Figures A1 and A2 in Appendix B suggest that Obama may have gained some momentum following his victory in the South Carolina primary that was lost on some VBM voters. Additionally, Obama may have been more likely to gain the support of Edwards' former supporters. Obama and Clinton supporters' turnout decisions may have been differentially affected by being assigned to VBM. Finally, campaign advertising or debates may also have affected the relative standing of Clinton and Obama. Any or all of these explanations are potential mechanisms for the results observed in Table 1.

Our point estimates suggest that the use of VBM may have had a substantial effect on the final vote margin in the California Democratic primary. Clinton beat Obama by about eight percentage points. Roughly 40 percent of ballots were cast by mail in the Democratic race. Being forced to use VBM increased Clinton's vote share relative to Obama's by about 10 percentage points. If we extrapolate our estimates to apply to those who select into VBM, about half of the eight percentage point final margin would have been erased if only polling place voting was used. Moreover, because the Democratic Party partially allocates delegates on a proportional basis, a loss of four percentage points would have cost Clinton some delegates. ${ }^{18}$

We also find that the use of VBM benefited Mike Huckabee relative to John McCain and Mitt Romney, consistent with Huckabee receiving a burst of momentum following his surprise Iowa caucus victory, which had dissipated by the time of Super Tuesday a month later. Table 2 presents regression results of the effect of VBM on the difference between Huckabee's and McCain's vote shares. The naïve OLS regression in column (1) shows a large negative correlation between Huckabee's relative performance and the use of VBM. However, consistent with our information loss hypothesis, the sign flips when we instrument for the percentage of VBM ballots with VBM-only status in columns (2)-(4). In the matched sample we find a significant

\footnotetext{
${ }^{18}$ Let $x$ be margin if only polling place voting is used. Plugging in parameters, $.4(10+x)+.6 x=8$, or $x=4$. We cannot estimate the specific number of delegates that would have been lost because they are awarded according to performance within congressional districts.
} 
positive effect of 2.5 percentage points $(p<.10$, two-tailed). The point estimate is slightly larger in the caliper matched sample, but the standard error is such that it is no longer statistically significant at conventional levels. Using the RDD-based approach, we obtain positive effects of around four percentage points. Applying a bandwidth of 100 , the effect of VBM on Huckabee's vote share relative to McCain is statistically significant at the $p<.10$ level. As shown in Figure 4B, this effect is robust to various bandwidth selections. ${ }^{19}$

Our finding that Huckabee's support was significantly greater among VBM voters builds upon existing literature on momentum in sequential elections such as presidential primaries. This literature suggests that performance in early contests provides candidates with momentum that assists them in later elections. California voters received their ballots on January 7th, only four days after Huckabee's victory in the Iowa caucus. Thus, VBM voters had the opportunity to cast ballots immediately after the Iowa victory and before a number of subsequent elections in which Huckabee performed poorly. Consistent with past results in the laboratory and in surveys, we show that observing these poor election performances caused a significant reduction in the likelihood of supporting Huckabee. Hence, voters may be holding something akin to "running tallies" of previous election results in determining their vote choice. Moreover, the fact that voters may underestimate the extent to which future information may sway their votes calls into question assumptions of pure rationality made by several recent papers that have attempted to formalize the idea of momentum in sequential elections (e.g., Callander 2007).

One alternative explanation for Huckabee's worse performance relative to McCain among polling place voters is that former Giuliani and Thompson voters disproportionately switched to voting for McCain. To assess this, we also examined the vote share of Romney relative to McCain. If Giuliani and Thompson supporters went predominantly to McCain, we would expect Romney to perform relatively better than McCain among VBM voters. However, unlike what we observed with Huckabee, we found small and generally insignificant estimates of the effect of VBM on Romney's relative performance to McCain (see Table 2 and Figure 4D). Thus, while the switching behavior of former Giuliani and Thompson voters may explain some portion of the gap between
Huckabee and McCain on VBM ballots (e.g., Romney and McCain split their support), the magnitudes of the coefficients in Table 2 are such that it cannot explain it entirely. Thus, we conclude that some Huckabee VBM supporters would have voted for Romney or McCain in the polling place on Election Day.

We next assess the effects of VBM on support for withdrawn candidates. We do this for two reasons. First, it serves as a robustness check that our findings above result from information revealed at the end of the campaign. That is, if not being exposed to late-breaking events causes VBM voters to disproportionately support candidates who have lost relative standing in the race, it should also cause VBM voters to disproportionately support candidates who withdrew from the race after mail ballots were received. More importantly, we can also use the estimated effects sizes to approximate the percentage of VBM voters who were affected by information loss. Because candidate withdrawals are unambiguous sources of vote-relevant information provided to voters before Election Day, they establish a benchmark to help us understand the effects of more ambiguous campaign events. Moreover, we know precisely when the information about candidate withdrawals is revealed. Thus we can use these quantities to extrapolate our results to learn about the potential impact of other events that occur in a similar time interval prior to Election Day.

Consistent with VBM voters being less likely to incorporate information about candidate withdrawals into their votes, we find that candidates who withdrew from the election in the days before Super Tuesday received greater support among VBM voters. The bottom row of Table 1 presents the effects of VBM on John Edwards' vote share. As a baseline for comparison, we first estimate an OLS regression with Edwards' vote share simply regressed on the percentage of VBM ballots in the precinct, along with county fixed effects. As shown in column (1) of Table 1 , the estimate is .081, implying that in a precinct that is wholly VBM, John Edwards received, on average, 8.1 more percentage points of the vote as compared to a precinct that entirely

\footnotetext{
${ }^{19} \mathrm{We}$ also calculated treatment estimates of Huckabee's momentum using Romney's vote share as the baseline. As shown in Table 2 and Figure 4C, we obtained very similar results as when we compare Huckabee to Romney.
} 

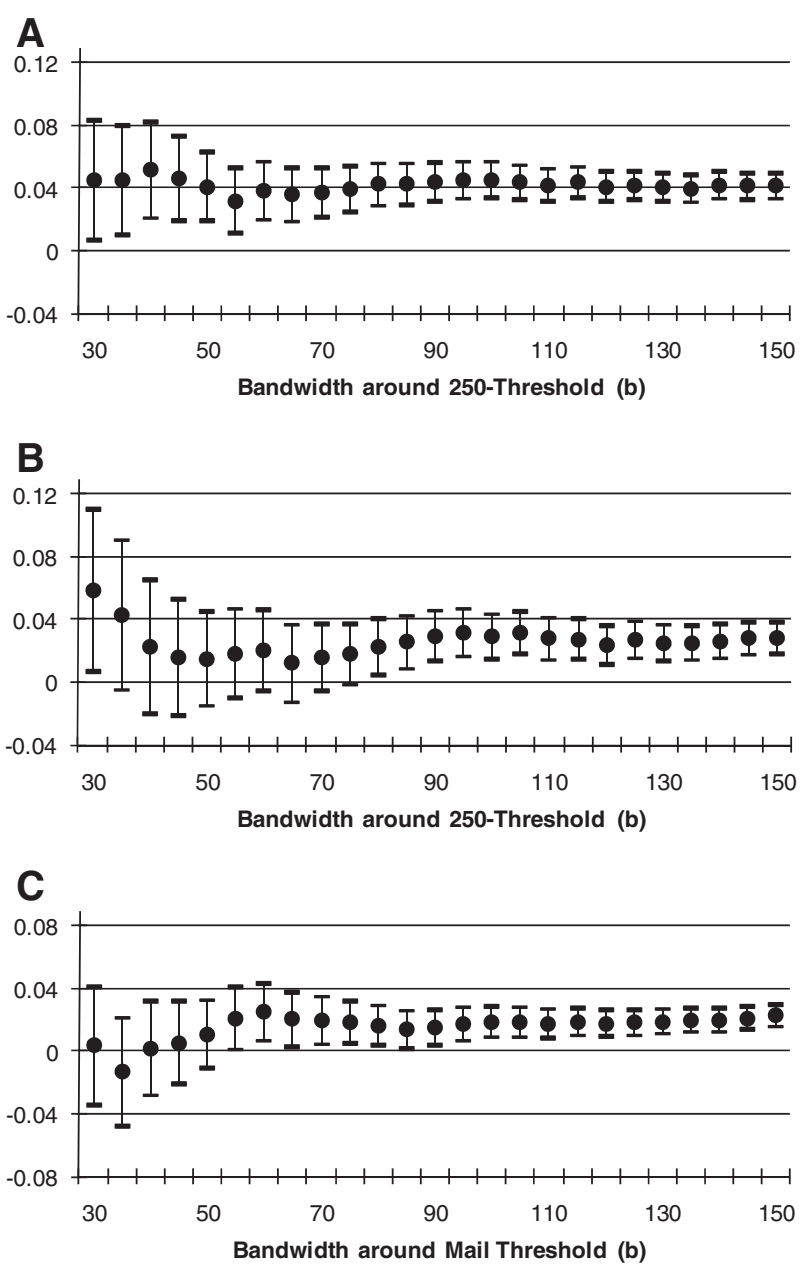

FIG. 5. Effects of VBM on support for withdrawn candidates. Circles indicate point estimates, bars indicate $95 \%$ confidence interval. (A) Effect of VBM on Edwards' vote share. (B) Effect of VBM on Giuliani's vote share. (C) Effect of VBM on Thompson's vote share.

consists of polling place voters. In columns (2)-(4) of Table 1 we present instrumental variable (IV) estimates of the effects of mail balloting using VBM-only status as the instrument for percentage of VBM ballots for the full sample, the matched sample, and the caliper-matched sample. ${ }^{20}$ We obtain a point estimate of 3.8 percentage points on the effect of VBM on Edwards' vote share in the caliper-matched sample, which is highly statistically significant at conventional levels $(p<.001$, two-tailed $){ }^{21}$

We find similar results using the RDD-based approach. Columns (5)-(7) of Table 1 report estimates using bandwidths of $b=\{50,75,100\}$. We obtain point estimates for the effect of VBM on Edwards vote share of between 3.9 and 4.5 percentage points, which are again highly statistically significant at conventional levels $(p<.001$, two-tailed in all cases).
The top panel of Figure 5 indicates that these point estimates are not sensitive to the choice of bandwidth. Thus, we find that VBM voters were less likely to incorporate information about Edwards' exit from the race into their vote choices. ${ }^{22}$

Similar results were observed in the Republican primary, with Giuliani and Thompson receiving significantly greater support among VBM voters. Table 2 presents estimates of the effect of VBM on Republican candidates' vote shares. We first analyze results obtained using matching. We find in the calipermatched sample that moving from a precinct with no VBM ballots to all VBM ballots increases Giuliani's and Thompson's vote shares by 3.2 and 2.5 percentage points $(p<.001$, two-tailed $)$, respectively. The RDD-based point estimates tend to be slightly smaller and somewhat sensitive to the bandwidth (see Figure 5B and Figure 5C), suggesting a gain of about 1.5 to 3.5 percentage points for Giuliani and 1.0 to 2.5 percentage points for Thompson. These estimated effects are statistically significant at the 95\% level for larger bandwidths (roughly $b>75$ ).

To assess what these results tell us more generally about voters' responses to late campaign information, we want to estimate what percentage of Edwards, Giuliani, and Thompson supporters did not incorporate information about their exit when casting VBM ballots. To make this calculation, we need to know the baseline levels of support that Edwards, Giuliani, and Thompson had prior to dropping out of the race. While the precinct-level election data cannot provide these baselines directly, we can

\footnotetext{
${ }^{20}$ In the language of Angrist, Imbens, and Rubin (1996), the IV adjusts the difference in election outcomes in VBM-only and traditional precincts by the difference in the compliance percentage (e.g., the increase in the percentage of individuals who use VBM in VBM-only precincts relative to traditional precincts).

${ }^{21}$ Our findings are subject to standard caveats regarding ecological inference since we do not observe individual vote choices and the timing of these individual choices. To interpret these as individual-level parameters, we need to assume that individuals who would also VBM in traditional precincts were unaffected by being in a VBM-only precinct.

${ }^{22}$ Another potential explanation for this result is that Edwards' supporters turned out to support him when using VBM, but did not turn out to vote in polling places. Although our method is not well suited to detect heterogeneous turnout effects like this, such behavior would imply greater overall turnout in VBM-only precincts versus traditional precincts. In contrast, we find that there is a small, statistically significant decrease in turnout in VBM-only precincts of a similar magnitude to what Kousser and Mullin (2007) find.
} 
approximate what they likely were using previous election results and polling data. The California Field Poll, taken between January 13th and January 20th, found Edwards receiving about 10 percent support on the Democratic side, and Giuliani and Thompson receiving about 11 and 9 percent support on the Republican side, respectively. These levels of support are broadly consistent with other polls and primary election results observed over this time period. If we assume that each candidate had about ten percentage points of support between when VBM ballots were mailed and his exit from the race and zero after his exit, our estimates suggest that about 35 to 50 percent of Edwards' supporters (i.e., 3.5-5 divided by 10), 15 to 35 percent of Giuliani's supporters, and 10 to 25 percent of Thompson's supporters would have voted differently if they had not been using VBM. ${ }^{23}$ Thus, VBM produces information loss among a sizeable portion of VBM, even when the information is revealed more than two weeks prior to the election.

When interpreting our results, it is important to consider the local average treatment effect (LATE) property of IV estimation. IV estimates the treatment effect for those whose treatment status is affected by the instrument, which in this case are voters who would choose to vote in a polling place if they were not forced to VBM. The IV results do not provide any insight about whether similar patterns would hold for those voters who choose to VBM. However, the cross-sectional correlations between mail voting and the vote shares of Edwards, Giuliani, and Thompson reported in column (1) of Tables 1 and 2 suggest that similar effects likely hold for voters selecting VBM.

\section{CONCLUSION}

Hopeful of increasing turnout and decreasing costs, elections officials around the county have greatly increased their use of convenience voting in recent years. Whereas existing research has focused on turnout implications (e.g., Southwell and Burchett 2000; Berinsky et al. 2001; Kousser and Mullin 2007) or partisan impacts (e.g., Stein 1998; Baretto et al. 2006; Dyck and Gimpel 2005; Berinsky 2005), this article addressed a totally unexplored question: Does convenience voting affect election outcomes by eliminating late campaign information for some voters?
We find that withdrawn candidates perform significantly better in the 2008 California presidential primary in precincts where VBM ballots are mandated. Moreover, the relative performance of remaining candidates is affected by VBM as well. This suggests that VBM voters did not fully incorporate information about candidate withdrawals and momentum. It also suggests that VBM voters presumably failed to incorporate other potentially vote relevant pieces of late information, such as the Democratic debate that took place in Los Angeles a few days before the election. Although we use VBM for analytical leverage, this study speaks to forms of early voting more broadly. Moreover, while this analysis focuses on a single election, we believe that the estimates are informative about information loss in other contexts. ${ }^{24}$

To speculate about what these results tell us about VBM and campaign effects more generally, note that Edwards and Giuliani exited six days before Election Day. Given that potentially relevant campaign information has come out in the last week of recent presidential campaigns, this suggests that convenience voting could have important effects on general election outcomes. For instance, in the 2000 election, Karl Rove's internal data suggested that George W. Bush lost 4 million evangelical votes due to the news of his DUI conviction, which Bush acknowledged five days before the election (Denton 2005; Rove 2010). Additionally, internal analyses by Kerry advisors Mary Beth Cahill and Mark Mellman suggested that the release of an al Qaeda tape featuring Osama bin Laden three days before the 2004 election primed terrorism in voters' minds, reducing Kerry's vote share (Harvard Institute of Politics 2006).

One policy concern raised by these results is that convenience voting may become grounds for individuals to question the legitimacy of an election.

\footnotetext{
${ }^{23}$ Note that we would obtain estimates nearly twice as large if we relied on the OLS estimates for Edwards, highlighting the need for the instrumental variable.

${ }^{24}$ One caveat is that there are likely to be fewer marginal voters in general elections than primary elections. In other words, voters may be less likely to change their vote choice in general elections due to the massive influence of party cues. Additionally, there are likely to be a greater number of "strategic" voters (Abramson et al. 1992) in primaries, or those who change their votes according to the relative standing of remaining candidates (which is revealed as the campaign progresses) in order to maximize the chances of voting for a viable candidate.
} 
An example is the special election held on November 3, 2009 in the 23rd District in upstate New York to replace retiring Republican Representative John M. McHugh. Voters selected among three major candidates: Democrat Bill Owens, moderate Republican Dierdre Scozzafava, and Doug Hoffman, who was nominated on the Conservative Party line. Three days before the election Scozzafava, who was suffering declining poll numbers in the face of opposition from conservative Republicans, withdrew from the race and endorsed the Democratic candidate. Owens ultimately won the election over Hoffman by 2.3 percentage points, with Scozzafava also receiving 5.7 percentage points of the vote. Many of these Scozzafava voters cast their ballots absentee prior to Scozzafava's announcement. ${ }^{25}$ The fact that many of these voters would have voted differently if they had instead voted on Election Day was used by some in the conservative blogosphere to question the legitimacy of Owens' election. ${ }^{26}$

We believe that our results also have implications for the design of electoral systems. Because individuals may use convenience voting to question the legitimacy of a close election outcome (as in the NY-23 race discussed above), election officials have incentives to try and minimize its potential influence. Convenience voting began as early as late September in a number of states in the 2008 presidential election. This resulted in the first votes being cast prior to the first presidential debate in a number of states. Given the patterns observed in this article, elections officials may need to have more extensive discussions about when to begin early voting, given the tradeoff between information loss and convenience. This may be particularly important in primaries, where momentum plays an important role in affecting voter choice and candidates often drop out of the race. States might want to wait until closer to Election Day to send out mail ballots, or instruct people on ballots to make sure to wait until they are ready to make a decision before voting.

Additionally, this study suggests that the dual election system that exists in the U.S. today (with both early voting and Election Day voting) may benefit candidates with more resources. Candidates seem to be aware that voters may cast their ballots without waiting to receive all the relevant information. As a result, campaigns have attempted to reach voters on the same day that absentee ballots are mailed out in hopes of influencing voters at the time that decisions are made (O’Donnell 2010). Cleveland City Council candidate Chris Ronayne commented: "We're treating this as two elections - the early voting in August and the September 7 primary day." Because wellfunded campaigns have greater ability to fund two mobilization efforts, convenience voting may exacerbate the influence of money in politics.

Finally, our findings suggest a new method for studying how events during the campaign affect vote choice. A number of recent papers have used a variety of methods, including surveys, laboratory experiments, and observational studies, providing evidence that rejects the traditional "minimal effects" hypothesis of campaigns effects (e.g., Geer and Lau 2006; Hillygus and Jackman 2003; Holbrook 1996). We complement this literature by showing that voters significantly changed their vote choices in response to the campaign environment, leveraging data from outside the survey context. ${ }^{27}$ Moreover, our findings suggest a method for future research on campaign effects. Specifically, we find that if the selection process for VBM or early in-person voting can be modeled, one can compare differences between mail and polling place voters to study the effect of late campaign information (see also Montalvo 2008). To this end, we hope to extend the methodology developed in this article to study the effects of other late campaign events such as advertisements, thereby providing causallyidentified evidence from elections to supplement data collected in the laboratory or in surveys.

\section{REFERENCES}

Abramson, Paul R., John H. Aldrich, and David W. Rhode. 1992. "'Sophisticated' Voting in the 1998 Presidential Primaries." American Political Science Review. 86: 55-69.

\footnotetext{
${ }^{25}$ Voters in New York state can request an absentee ballot up to thirty days before Election Day. While New York does not publish results separately for absentee voters, we compared the preliminary vote totals from Nov. 5, 2009, prior to the counting of absentee ballots, with the final vote totals. Scozzafava received 4.7 percent of the vote counted before Nov. 5, 2009, compared to 14.5 percent of the vote counted after.

${ }^{26}$ The website of the Government Is Not God Political Action Committee proclaimed "Doug Hoffman would have won except for absentee ballots that had been cast for Scozzafava before Hoffman even entered the race." < http://www.gingpac .org/index.php?option $=$ com_content $\&$ view $=$ article $\&$ id $=118$ : december-2009-update \&catid $=1 \&$ Itemid $=100007>\quad($ Dec . 2009).

${ }^{27}$ In a similar spirit, Arceneaux, Kousser, and Mullin (2009) find differential effects of get-out-the-vote targeting in VBMonly and traditional precincts.
} 
"Absentee and Early Voting Laws." The Early Voting Information Center. 21 Feb. 2008. Reed College. Retrieved 26 Sept. $2008<$ http://www.earlyvoting.net/states/abslaws.php $>$.

Angrist, Joshua D., Guido W. Imbens, and Donald B. Rubin. 1996. "Identification of Casual Effects Using Instrumental Variables." Journal of the American Statistical Association 91: 444-455.

Arceneaux, Kevin, Alan S. Gerber, and Donald P. Green. 2006. "Comparing Experimental and Matching Methods Using a Large-Scale Voter Mobilization Experiment." Political Analysis. 14: 37-62.

Arceneaux, Kevin, Thad Kousser, and Megan Mullin. 2009. "Get Out the Vote By Mail? Evidence from a Natural/ Field Experiment." Presented at the Annual Meeting of the Society for Political Methodology.

Barber, Brad and Terrence Odean. 2001. "Boys Will Be Boys: Gender, Overconfidence, and Common Stock Investment." Quarterly Journal of Economics. 116: 261-292.

Baretto, Matt A., Matthew J. Streb, Mara Marks, and Fernando Guerra. 2006. "Do Absentee Voters Differ From Polling Place Voters? New Evidence from California." Public Opinion Quarterly. 70: 224-34.

Bartels, Larry M. 1988. Presidential Primaries and the Dynamics of Public Choice. Princeton, NJ: Princeton University Press.

Berinsky, Adam J. 2005. "The Perverse Consequences of Electoral Reform in the United States." American Politics Research. 33: 471-91.

Berinsky, Adam, Nancy Burns, and Michael Traugott. 2001. "Who Votes By Mail? A Dynamic Model of the Individual-Level Consequences of Vote-By-Mail Systems." Public Opinion Quarterly. 65: 178-97.

Brady, Henry E., and John E. McNulty. 2011. "Turning Out to Vote: The Costs of Finding and Getting to the Polling Place."American Political Science Review. 105: 115-134.

Callander, Steven. 2007. "Bandwagons and Momentum in Sequential Voting." Review of Economic Studies. 74: 653-84.

Camerer, Colin and Dan Lovallo. 1999. "Overconfidence and Excess Entry: An Experimental Approach.” American Economic Review. 89: 306-318.

Campbell, Angus, Philip E. Converse, Warren E. Miller, and Donald Stokes. 1960. The American Voter. New York: Wiley.

Carmines, Edward G., and James A. Stimson. 1980. "The Two Faces of Issue Voting." American Political Science Review. 74: 78-91.

Culter, Eliot. 2010. "Who Stole Election Day?” Wall Street Journal, November 17, 2010, accessed April 14, 2011, < http://online .wsj.com/article/SB1000142405274870332620457561689 0895700112.html > .

Curry, Tom. 2010. "Early Voting Transforms Strategy." MSNBC.com, October 4, 2010, accessed April 14, 2011, <http://www.msnbc.msn.com/id/39444285/ns/politicsdecision_2010>.

Daniel, Kent, David Hirshleifer, and Avanidhar Subrahmanyam. 1998. "Investor Psychology and Security Market Over- and Under-Reactions." Journal of Finance. 53: 1839-1886.

Denton Jr., Robert E. 2005. "Religion, Evangelicals, and Moral Issues in the 2004 Presidential Campaign.” The 2004 Presidential Campaign: A Communication Perspective. Ed. Robert E. Denton. New York: Rowman \& Littlefield. 255-82.
Dubin, Jeffrey A., and Gretchen A. Kalsow. 1996. "Comparing Absentee and Precinct Voters: Voting on Direct Legislation." Political Behavior. 18: 393-411.

Dunning, Thad. 2008. "Improving Causal Inference: Strengths and Limitations of Natural Experiments." Political Research Quarterly. 61: 282-293.

Dyck, Joshua J., and James G. Gimpel. 2005. "Distance, Turnout, and the Convenience of Voting." Social Science Quarterly. 86: 531-48

Fiorina, Morris P. 1976. "The Voting Decision: Instrumental and Expressive Aspects.” Journal of Politics. 38: 390-413.

Fiorina, Morris P. 1981. Retrospective Voting in American National Elections. New Haven, CT: Yale University Press.

Fournier, Patrick, Richard Nadeau, Andre Blais, Elisabeth Gidengil, and Neil Nevitte. 2004. "Time-of-Voting Decision and Susceptibility to Campaign Effects." Electoral Studies. 23: 661-81.

Geer, John, and Richard R. Lau. 2006. "Filling in the Blanks: A New Method for Estimating Campaign Effects.” British Journal of Political Science. 36: 269-90.

Government Is Not God Political Action Committee. "December, 2009 Campaign Update.” Retrieved May 7, 2010 from $<$ http://www.gingpac.org/index.php?option = com_content $\&$ view $=$ article $\&$ id $=118$ :december-2009-update\&catid $=$ $1 \&$ Itemid $=100007>$.

Gronke, Paul, Eva Galanes-Rosenbaum, Peter A. Miller, and Daniel Toffey. 2008. "Convenience Voting." Annual Review of Political Science. 11: 437-55.

Harvard Institute of Politics. 2006. Campaign for President: The Managers Look at 2004. Ed. Harvard Institute of Politics. Lanham, MD: Rowman \& Littlefield.

Hillygus, D. Sunshine, and Simon Jackman. 2003. "Voter Decision Making in Election 2000: Campaign Effects, Partisan Activation, and the Clinton Legacy." American Journal of Political Science. 47: 583-96.

"Historical Absentee Ballot Use in California." Elections and Voter Information. California Secretary of State. 26 Sept. 2008 $<$ http://www.sos.ca.gov/elections/ hist_absentee.htm > .

Ho, Daniel E., Kosuke Imai, Gary King, and Elizabeth A. Stuart. 2007. "Matching as Nonparametric Preprocessing for Reducing Model Dependence in Parametric Causal Inference." Political Analysis. 15: 199-236.

Holbrook, Thomas M. 1996. Do Campaigns Matter? Minneapolis, MN: Sage.

Imbens, Guido W. and Thomas Lemieux. 2008. "Regression Discontinuity Designs: A Guide to Practice." Journal of Econometrics 142: 615-635.

Kenney, Patrick J., and Tom W. Rice. 1994. “The Psychology of Political Momentum." Political Research Quarterly. 47: 923-38.

Knight, Brian, and Nathan Schiff. 2010. "Momentum and Social Learning in Presidential Primaries." Journal of Political Economy 118: 1110-1150.

Kousser, Thad, and Megan Mullin. 2007. “Does Voting By Mail Increase Participation? Using Matching to Analyze a Natural Experiment." Political Analysis. 15: 428-445.

Montalvo, Jose G. 2008. "Voting after the Bombing: Can Terrorist Attacks Change the Outcome of Democratic Elections?" Manuscript. Universitat Pompeu Fabra. 
Mutz, Diana C. 1999. Impersonal Influence: How Perceptions of Mass Collectives Affect Political Attitudes. New York: Cambridge University Press.

Neeley, Grant W., and Lilliard E. Richardson, Jr. 2001. "Who Is Early Voting? An Individual Level Examination.” Social Science Journal. 38: 381-92.

O’Donnell, Patrick. 2010. "Easy Absentee Ballots Mean Early Start for Cuyahoga County Campaign Rush." Cleveland Plain Dealer. Retrieved 22 Sep. 2010. < http:// blog .cleveland.com/metro/2010/08/campaigning_already_ underway_f.html $>$.

Patterson, Samuel C., and Gregory A. Caldeira. 1985. "Mailing In the Vote: Correlates and Consequences of Absentee Voting." American Journal of Political Science. 29: 766-88.

Rove, Karl. 2010. Courage and Consequence: My Life as a Conservative in the Fight. New York: Threshold Editions.

Southwell, Priscilla L., and Justin L. Burchett. 2000. "The Effect of All-Mail Elections on Voter Turnout." American Politics Research. 28: 72-79.

Stein, Robert M. 1998. "Early Voting." Public Opinion Quarterly. 62: 57-69.
Stein, Robert M. 2009. "The Effects of Early Voting on Congressional Compaign Expenditures: 1980-2004.” APSA 2009 Toronto Meeting Paper.

Stein, Robert M., Jan E. Leighley, and Chris Owens. 2004. "Voting, Early Voting, and Party Mobilization: Is Timing Everything?" Paper presented at the Annual Meeting of the Midwest Political Science Association, Chicago, IL.

Svenson, Ola. 1981. "Are We All Less Risky and More Skillful Than Our Fellow Drivers?” Acta Psychologia. 47: 143-148. Thistlewaite, Donald L, and Donald T. Campbell. 1960 "Regression-Discontinuity Analysis: An Alternative to the Ex-post Facto Design." Journal of Educational Psychology. 51: 309-317.

Address correspondence to: Marc Meredith

University of Pennsylvania Department of Political Science 208 S. 37th Street, Room 217 Philadelphia, PA 19106

E-mail:marcmere@sas.upenn.edu 


\section{APPENDIX A: TECHNICAL APPENDIX}

\section{Imputation of missing data}

As noted in footnote 11 , we are missing precinctlevel data on the percentage of voters casting VBM ballots in Orange, San Mateo, and Tuolumne counties. This information is used in our analysis to calculate the differences in the percentage of voters using VBM in VBM-only and comparison traditional precincts. Specifically, it is used to scale the differences in candidate vote share outcomes we observe in VBM-only and comparison traditional precincts. For example, suppose 40 percent more votes are cast using VBM ballots in VBM-only precincts than in comparison traditional precincts. Then if a candidate's vote share is 2.5 percentage points higher in VBM-only precincts, our estimated treatment effect is that a one percentage point increase in VBM increases the candidate's vote share by $0.025 / 0.4=$ 0.1 percentage points.

For these three counties with missing data we assume that the percentage of Democratic and Republican ballots cast by VBM in the comparison traditional precincts equal the percentage of ballots cast by VBM countywide in the Democratic and Republican primaries, respectively. We also assume that 100 percent of the ballots are cast by VBM in the VBM-only precincts. To check the validity of this approximation, we examine how close this imputation method comes to replicating the actual differences in the 37 counties where we actually do observe the full data. The mean and median deviation (i.e., the absolute value between the actual difference and what we would impute if the data were not observable using our method) is only about 5 and 2.5 percentage points, respectively. Moreover, in large counties this difference is generally even smaller. Thus, we conclude that our imputation method is unlikely to significantly bias our estimates.

\section{Matching approach}

We use matching to generate a control group of traditional polling place precincts to compare to our VBM-only precincts. We specifically use withincounty Mahalanobis distance matching with replacement. For each of our VBM-only precincts, we find the traditional polling place in the same county that is the closest in terms of Mahalanobis distance on the eighteen variables list in Table A2 in Appendix B. In some analyses we also apply a caliper restriction that drops any match where any of the eighteen observable characteristics of the VBM-only precinct and the matched traditional precinct differ by more than one standard deviation. Once we have constructed our matched dataset, we regress candidate vote shares on the percentage of VBM ballots, instrumenting for the percentage of VBM ballots with VBM-only status. Because matching with replacement means that the same traditional precinct can be matched to multiple VBM-only precincts, we cluster standard errors by precinct in all of our analyses.

In our analysis we weight our matches to account for differential sampling variance caused by variation in the number of votes cast in each precinct. Let $Y_{v}$ and $Y_{t}$ be random variables representing a candidate's vote share in a VBM-only and matched traditional precinct, respectively. Likewise let $N_{v}$ and $N_{t}$ be the number of votes cast in a VBM-only and matched traditional precinct, respectively. Under a null hypothesis that voters in each precinct support the candidate with probability $p$, the sampling variance in the difference in between $Y_{v}$ and $Y_{t}$ is:

$\operatorname{var}\left(Y_{v}-Y_{t}\right)=\frac{p(1-p)}{N_{v}}+\frac{p(1-p)}{N_{t}}=\frac{\left(N_{v}+N_{t}\right) p(1-p)}{N_{v} N_{t}}$.

Following the well-established practice of weighting observations by the inverse of the sampling variance, we weight a given match by

$$
\frac{N_{v} N_{t}}{\left(N_{v}+N_{t}\right)} \text {. }
$$

\section{RDD-based approach}

RDD can potentially be implemented when the probability of a treatment variable being assigned changes discontinuously on the basis on the value of what is commonly referred to as a forcing variable. In our case the treatment is VBM-only status, which is assigned discontinuously based on whether the value of registered ${ }_{j}$ - a variable that equals the number of registrants in precinct $j$ on November 7, 2007-is less than or equal to 250. A standard approach for implementing an RDD is to use local linear regression to estimate how the assignment of the probability of casting a VBM ballot and voting for specific candidates changes based on whether registered $_{j}$ is just barely above or just barely below 250 (Imbens and Lemieux 2008).

What complicates our analysis is that we do not actually observe registered $_{j}$. Instead, we observe election_registered $_{j}$, which is the number of registrants in precinct $j$ on Election Day. We can also use the Voter File to construct late_registered ${ }_{j}$, which is the number of registrants observed in the voter file registering between November 7, 2007 and January 21, 2008, the last day on which voters could register and be eligible to vote in the election. Using these two quantities we construct approx_registered $_{j}=$ election_registered $_{j}$ - late_registered $d_{j}$, which is our approximation of the 
value of registered ${ }_{j}$. Our approximation could differ from the actual value for a number of reasons. Voters may have been purged from the rolls between November 7, 2007 and January 21, 2008. There also may be a lag such that voters registering just before November 7, 2007 were not included in the counts used to determine VBM-only status. Finally, there are likely some errors in our mapping from voter file precincts to consolidated precincts.

The measurement error generated by approximating registered r $_{j}$ with approx_registered $d_{j}$ prevents us from being able to implement a standard RDD analysis. As we would expect, Figure 3 illustrates that the percentage of VBM-only precincts decreases when approx_registered ${ }_{j}$ is above the 250-registrant threshold. However, Figure 3 also shows that measurement error generated by approximating registered ${ }_{j}$ with approx_registered $_{j}$ causes a substantial increase in misclassification near the threshold. Such misclassification is problematic for standard RDD designs that are based on comparing the change in treatment assignment at the threshold. For example, suppose approx_registered $d_{j}=$ registered $_{j}+\varepsilon_{j}$, where $\varepsilon_{j}$ is distributed from a mean zero symmetric distribution. The limit on the probability of receiving the treatment as approx_registered $d_{j}$ approaches 250 from both above and below will be .5 .

Because we cannot perform a standard RDD analysis, we develop an RDD-based approach that utilizes the variation generated by the discontinuous assignment of the treatment. The motivation taken from an RDD is that we would like to compare precincts with values of approx_registered $d_{j}$ just below 250 to precincts with values of approx_registered ${ }_{j}$ just above 250. However, we need to do so in a way that does not require us to leverage discontinuous changes in limits at a specific value of approx_registered $d_{j}$. Further complicating this analysis is that precincts with values of approx_registered $d_{j}$ just above 250 do not look observably identical to precincts with values of approx_registered $_{j}$ just below 250. Define $b$ as the bandwidth parameter from which we set bounds on the values of approx_registered ${ }_{j}$ used in this comparison (e.g., compare precincts with values of $251-b$ and 250 to precincts with values of approx_registered between 251 and $250+b$ ). Table A2 in Appendix B shows that even when $b$ is relatively small, voter characteristics are substantially different in places with values of approx_registered ${ }_{j}$ just above and below the 250-threshold.

Our solution for overcoming this identification problem is to compare precincts with values of approx_registered $_{j}$ near the 250-registrant threshold to geographically proximate precincts well above the 250-registrant threshold. The motivation for our approach is the difference-in-difference specification that is illustrated by the following example. Suppose that precincts $i=\{1,2\}$ are in census tract $t$ and precincts $\{3,4\}$ are in census tract $t$ ' such that $251-b \leq$ approx_registered $_{1} \leq 250 \leq$ approx_registered $_{3} \leq 250$ $+b \leq$ approx_registered $_{2}$, approx_registered 4 . Let $Y_{i}$ and $m_{i}$ be a candidate's vote share and the percentage of VBM ballots cast in precinct $i$, respectively. Because precinct 1 is below and precinct 3 is above the 250-registrant threshold, $m_{l}$ should be greater than $m_{3}$. However, we are concerned that simply relating $m_{1}-m_{3}$ to $Y_{1}-Y_{3}$ might confound differences in the use of VBM with differences in the types of voters that live in census tract $t$ and $t^{\prime}$. However, because neither $Y_{2}$ nor $Y_{4}$ is a VBM-only precinct, we expect that we can use $Y_{2}-Y_{4}$ to approximate the counterfactual difference between $Y_{1}-Y_{3}$ if there were no difference in the use of VBM. Thus, relating $\left(m_{1}-m_{3}\right)-\left(m_{2}-\right.$ $\left.m_{4}\right)$ to $\left(Y_{1}-Y_{3}\right)-\left(Y_{2}-Y_{4}\right)$ may provide a better estimate of the effect of VBM.

The approach highlighted in the previous paragraph is formalized in equations (1) and (2). Define $t(j)$ to be a function that returns the index of the primary census tract of precinct $j$ (e.g., the census tract which contains a plurality of the population living in precinct $j$ ), and let $\lambda_{t(j)}$ be a census tract fixed effect. Similarly, define $c(j)$ to be a function that returns the index of the county of precinct $j$, and let $\lambda_{c(j)}$ be a county-specific-fixed-effect for observations with values of approx_registered ${ }_{j}$ within $b$ units of the threshold. Our goal is to estimate $\theta$, the percentage point change in a candidate's vote share from a one percentage point change in the percentage of mail ballots cast in the precinct. However, we cannot estimate (1) via OLS because we do not believe that $\mathrm{E}\left[\varepsilon_{j} \mid m_{j}\right]=0$. However, we can use I(251-b $\leq$ approx_registered $\left._{j} \leq 250\right)$, an indicator for whether there is more than 250 approximate registrants, as an instrument to estimate (1) and (2) with two-staged least squares. When estimating equations (1) and (2), we weight observations by the number of 2008 primary votes in the precinct.

$$
\begin{aligned}
Y_{j}= & \lambda_{t(j)}+\lambda_{c(j)} I\left(251-\mathrm{b} \leq \text { approx_registered }_{j}\right. \\
& \leq 250+b)+\theta m_{j}+\varepsilon_{j} \\
m_{j}= & \delta_{t(j)}+\delta_{c(j)} I\left(251-\mathrm{b} \leq \text { approx_registered }_{j}\right. \\
& \leq 250+b)+\beta_{1}\left(251-\mathrm{b} \leq \text { approx_registered }_{j}\right. \\
& \leq 250)+\eta_{j}
\end{aligned}
$$

Following Dunning (2008), we show that our instrument in equation (2) does not systematically relate to other observables. Table A3 and Figure A3 in Appendix $B$ illustrate the coefficient and standard error on the estimate of $\beta$ when we replace the dependent variable in equation (2) with other voter characteristics or precinct demographics. 


\section{APPENDIX B}
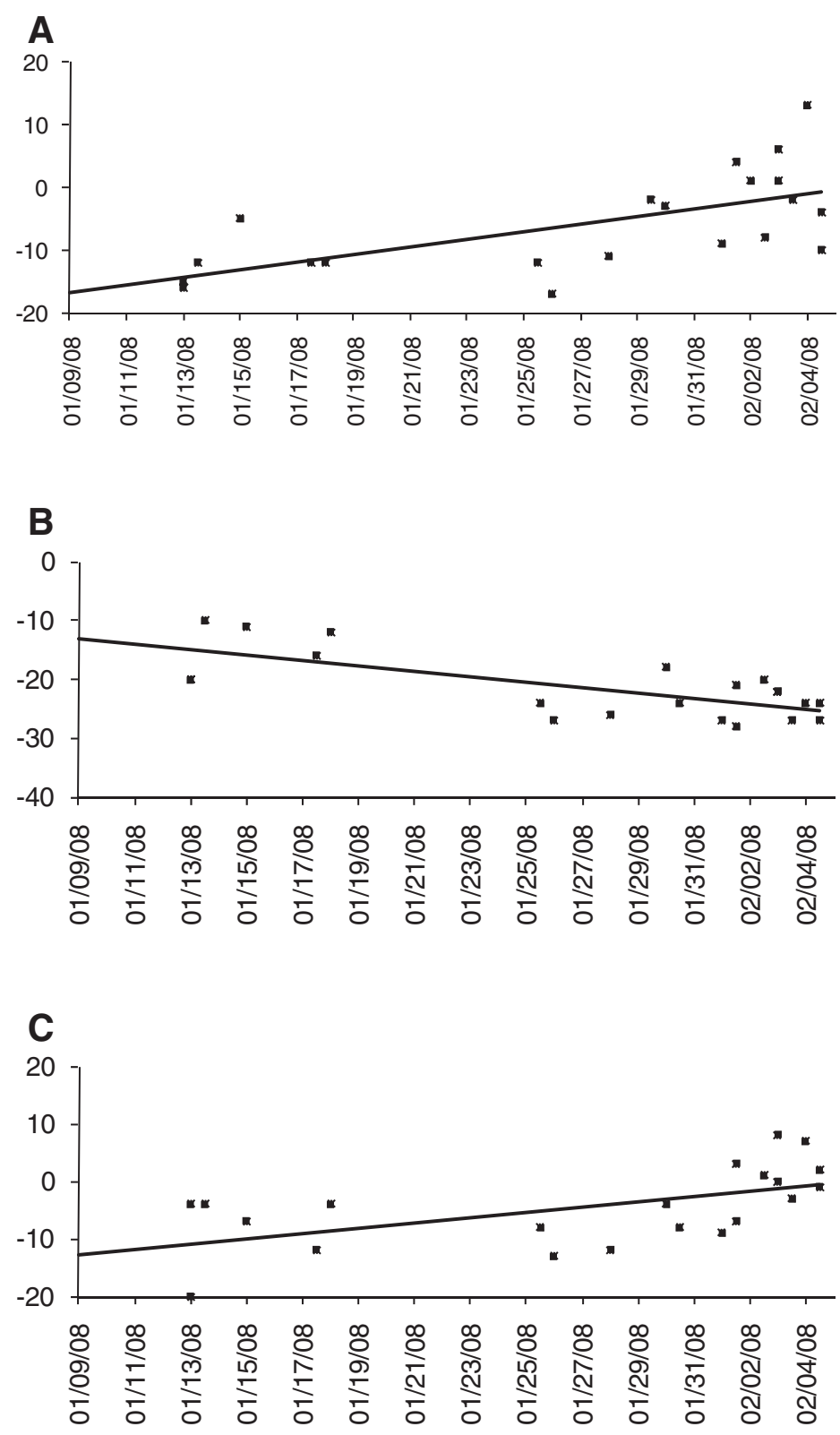

FIG. A1. Difference in the percent of Californians supporting candidates in pre-election polls by date of poll. (A) \% Obama$\%$ Clinton. (B) \% Huckabee-\% McCain. (C) \% Romney-\% McCain. Poll date is the median date that the poll was in the field. Black lines indicate linear trend. Data obtained from <http://www.pollster.com/polls/ca/08-ca-rep-pres-primary.php> and <http://www.pollster.com/polls/ca/08-ca-dem-pres-primary.php> on Dec. 5, 2008. 
A

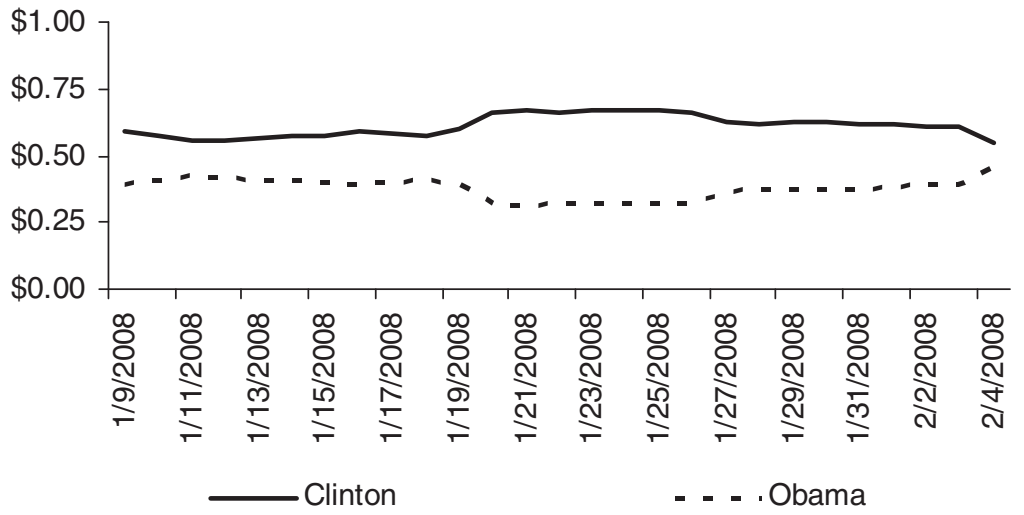

B

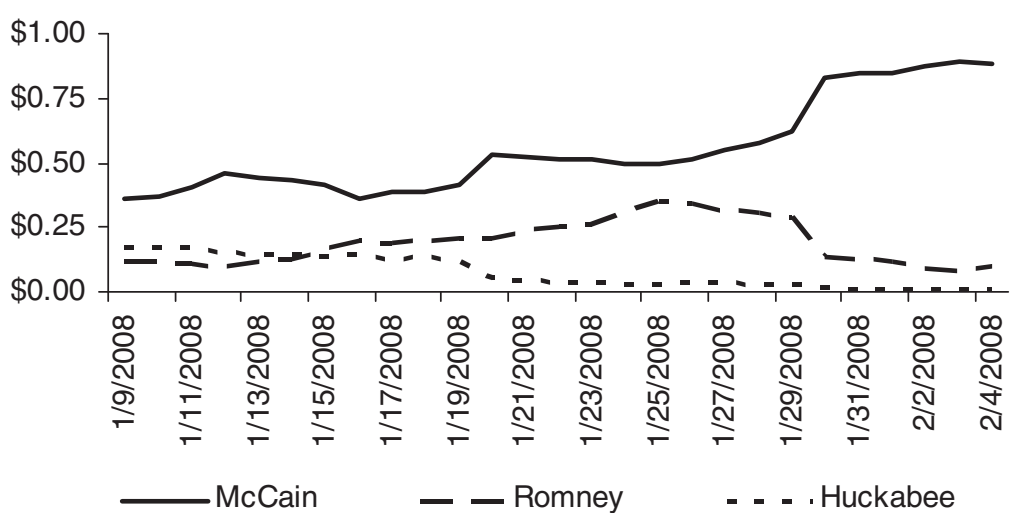

FIG. A2. Median price of $\$ 1$ contract on Intrade on candidate to win nomination. (A) Democratic nomination. (B) Republican nomination. 

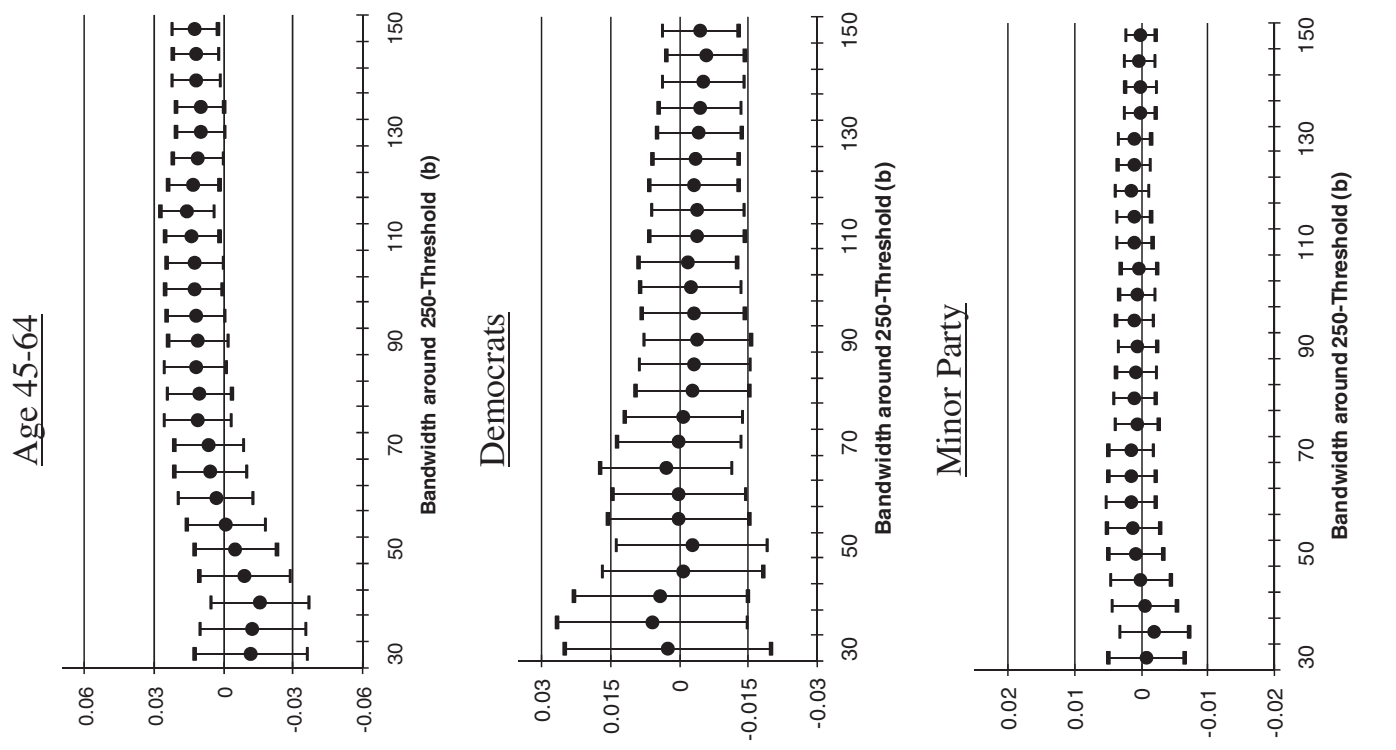

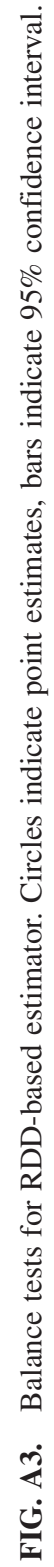
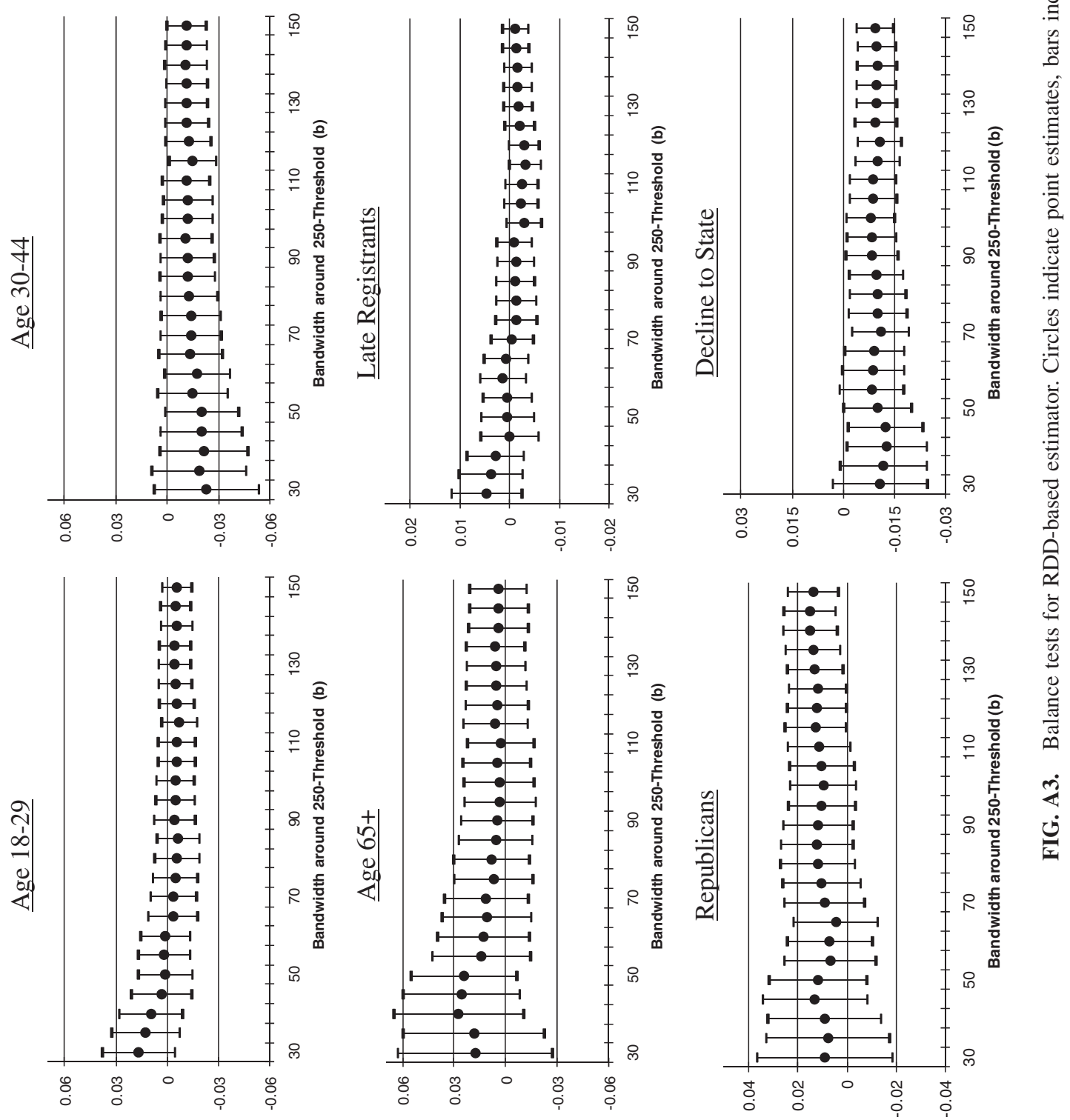

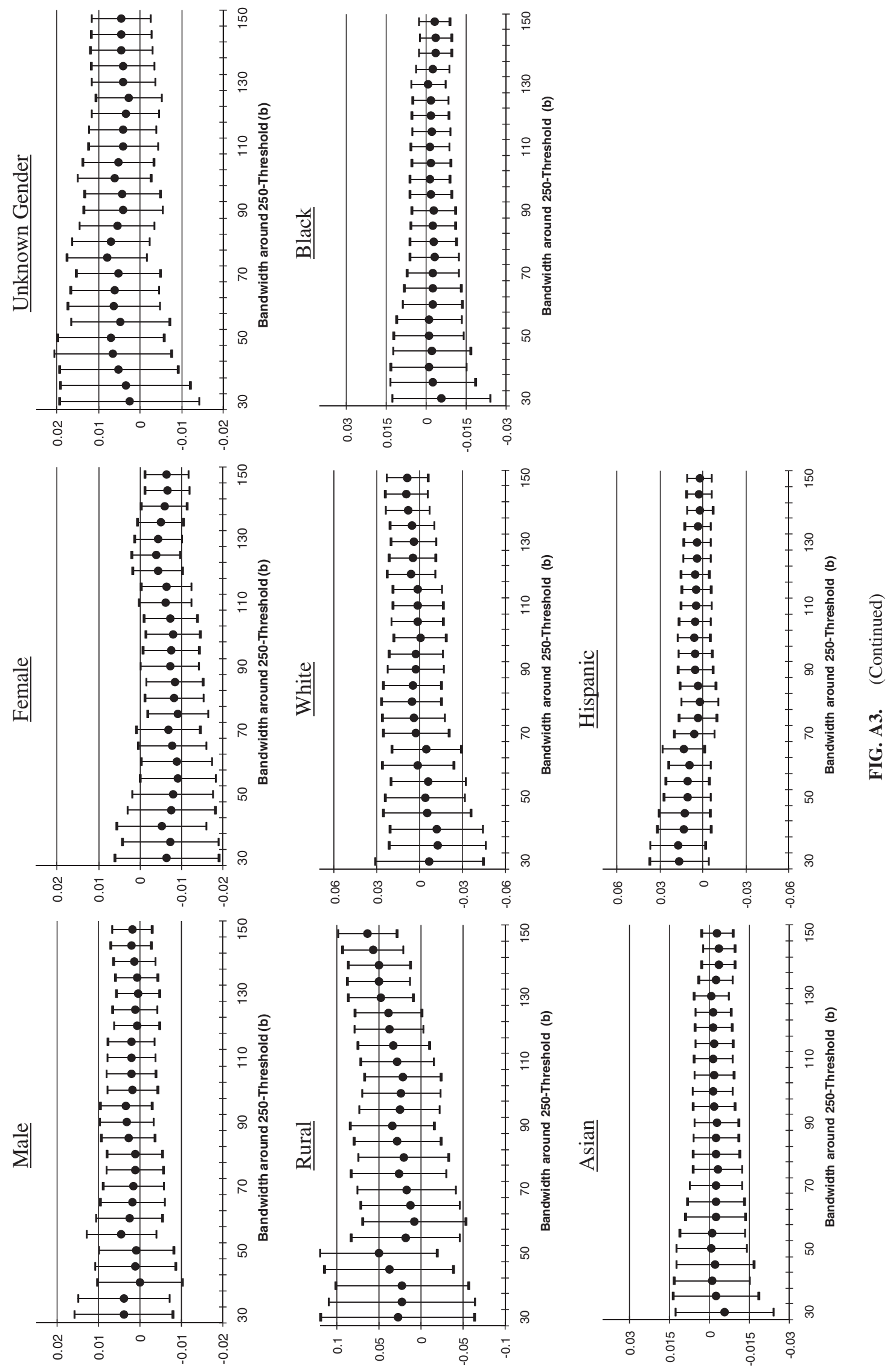
Table A1. Excluded Counties

\begin{tabular}{|c|c|}
\hline County & Reason for Exclusion \\
\hline Alpine & Only VBM-only precincts \\
\hline Amador & Single VBM-only precinct \\
\hline Butte & $\begin{array}{l}\text { Could not provide full documentation } \\
\text { of excluded registrants }\end{array}$ \\
\hline Calaveras & Only traditional precincts \\
\hline Del Norte & Only traditional precincts \\
\hline El Dorado & $\begin{array}{l}\text { Could not provide full documentation } \\
\text { of excluded registrants }\end{array}$ \\
\hline Inyo & $\begin{array}{l}\text { Unable to observe the treatment } \\
\text { assignment variable }\end{array}$ \\
\hline Merced & $\begin{array}{l}\text { Could not provide full documentation } \\
\text { of excluded registrants }\end{array}$ \\
\hline Monterey & $\begin{array}{l}\text { Results and discontinuity at different } \\
\text { levels of aggregation }\end{array}$ \\
\hline Napa & $\begin{array}{l}\text { Could not provide full documentation } \\
\text { of excluded registrants }\end{array}$ \\
\hline Nevada & $\begin{array}{l}\text { Unable to observe the treatment } \\
\text { assignment variable }\end{array}$ \\
\hline Riverside & $\begin{array}{l}\text { Could not provide full documentation } \\
\text { of excluded registrants }\end{array}$ \\
\hline San Diego & $\begin{array}{l}\text { Unable to observe the treatment } \\
\text { assignment variable }\end{array}$ \\
\hline San Luis Obispo & $\begin{array}{l}\text { Unable to observe the treatment } \\
\text { assignment variable }\end{array}$ \\
\hline Sierra & Only VBM-only precincts \\
\hline Sutter & $\begin{array}{l}\text { Unable to observe the treatment } \\
\text { assignment variable }\end{array}$ \\
\hline Trinity & $\begin{array}{l}\text { Unable to obtain precinct-level } \\
\text { data }\end{array}$ \\
\hline Tulare & $\begin{array}{l}\text { Unable to observe the treatment } \\
\text { assignment variable }\end{array}$ \\
\hline
\end{tabular}

Table A2. Balance Tests for Matching Estimator

\begin{tabular}{|c|c|c|c|}
\hline & $\begin{array}{c}\text { (1) } \\
\text { Full Sample }\end{array}$ & $\begin{array}{c}\text { (2) } \\
\text { Matched }\end{array}$ & $\begin{array}{c}\text { (3) } \\
\text { Caliper Matched }\end{array}$ \\
\hline Observations & 16,859 & 4,101 & 1,296 \\
\hline Mail Precincts & 2,507 & 2,507 & 707 \\
\hline Traditional Precincts & 14,352 & 1,594 & 589 \\
\hline$\%$ Mail Ballots & $\begin{array}{c}0.493 \\
(0.004)\end{array}$ & $\begin{array}{c}0.481 \\
(0.006)\end{array}$ & $\begin{array}{c}0.472 \\
(0.006)\end{array}$ \\
\hline$\%$ Rural & $\begin{array}{c}0.294 \\
(0.010)\end{array}$ & $\begin{array}{c}0.055 \\
(0.024)\end{array}$ & $\begin{array}{c}0.013 \\
(0.030)\end{array}$ \\
\hline$\%$ White & $\begin{array}{c}0.036 \\
(0.010)\end{array}$ & $\begin{array}{r}-0.006 \\
(0.018)\end{array}$ & $\begin{array}{r}-0.005 \\
(0.021)\end{array}$ \\
\hline$\%$ Black & $\begin{array}{c}-0.012 \\
(0.006)\end{array}$ & $\begin{array}{c}0.001 \\
(0.002)\end{array}$ & $\begin{array}{r}-0.001 \\
(0.003)\end{array}$ \\
\hline$\%$ Asian & $\begin{array}{c}-0.027 \\
(\mathbf{0 . 0 0 6})\end{array}$ & $\begin{array}{c}-0.001 \\
(0.003)\end{array}$ & $\begin{array}{c}-0.001 \\
(0.005)\end{array}$ \\
\hline \% Hispanic & $\begin{array}{c}0.004 \\
(0.006)\end{array}$ & $\begin{array}{c}0.006 \\
(0.005)\end{array}$ & $\begin{array}{c}0.006 \\
(0.006)\end{array}$ \\
\hline$\%$ Age 18-29 & $\begin{array}{r}-0.015 \\
(0.004)\end{array}$ & $\begin{array}{c}-0.001 \\
(0.003)\end{array}$ & $\begin{array}{r}-0.002 \\
(0.003)\end{array}$ \\
\hline$\%$ Age 30-44 & $\begin{array}{r}-0.030 \\
(0.004)\end{array}$ & $\begin{array}{r}-0.007 \\
(0.003)\end{array}$ & $\begin{array}{r}-0.004 \\
(0.004)\end{array}$ \\
\hline$\%$ Age 45-64 & $\begin{array}{c}0.024 \\
(0.004)\end{array}$ & $\begin{array}{c}0.002 \\
(0.004)\end{array}$ & $\begin{array}{c}0.001 \\
(0.005)\end{array}$ \\
\hline$\%$ Age $65+$ & $\begin{array}{c}0.020 \\
(0.005)\end{array}$ & $\begin{array}{c}0.006 \\
(0.005)\end{array}$ & $\begin{array}{c}0.005 \\
(0.006)\end{array}$ \\
\hline$\%$ Democratic & $\begin{array}{c}-0.028 \\
(0.006)\end{array}$ & $\begin{array}{c}0.000 \\
(0.006)\end{array}$ & $\begin{array}{c}0.001 \\
(0.008)\end{array}$ \\
\hline \% Republican & $\begin{array}{c}0.039 \\
(0.006)\end{array}$ & $\begin{array}{c}0.002 \\
(0.008)\end{array}$ & $\begin{array}{c}0.002 \\
(0.010)\end{array}$ \\
\hline$\%$ Decline to State & $\begin{array}{c}-0.013 \\
(0.002)\end{array}$ & $\begin{array}{r}-0.003 \\
(0.002)\end{array}$ & $\begin{array}{c}-0.003 \\
(0.003)\end{array}$ \\
\hline \% Minor Party & $\begin{array}{c}0.002 \\
(0.001)\end{array}$ & $\begin{array}{c}0.001 \\
(0.001)\end{array}$ & $\begin{array}{c}0.000 \\
(0.001)\end{array}$ \\
\hline$\%$ Male & $\begin{array}{c}0.003 \\
(0.002)\end{array}$ & $\begin{array}{c}0.000 \\
(0.009)\end{array}$ & $\begin{array}{c}-0.001 \\
(0.011)\end{array}$ \\
\hline$\%$ Female & $\begin{array}{r}-0.009 \\
(0.002)\end{array}$ & $\begin{array}{c}-0.002 \\
(0.009)\end{array}$ & $\begin{array}{r}-0.002 \\
(0.012)\end{array}$ \\
\hline \% Unknown Gender & $\begin{array}{c}0.006 \\
(0.003)\end{array}$ & $\begin{array}{c}0.002 \\
(0.018)\end{array}$ & $\begin{array}{c}0.003 \\
(0.023)\end{array}$ \\
\hline \% Late Registrants & $\begin{array}{c}0.001 \\
(0.001)\end{array}$ & $\begin{array}{c}0.002 \\
(0.001)\end{array}$ & $\begin{array}{c}-0.001 \\
(0.001)\end{array}$ \\
\hline $\begin{array}{l}\text { \% Absentee } \\
\text { (Santa Clara Only) }\end{array}$ & $\begin{array}{c}0.011 \\
(0.005)\end{array}$ & $\begin{array}{r}-0.004 \\
(0.012)\end{array}$ & $\begin{array}{c}-0.001 \\
(0.008)\end{array}$ \\
\hline
\end{tabular}

Values show percentage point difference in VBM-only relative to traditional precincts. Standard errors in parenthesis. Bold indicates a significant difference at $95 \%$ level. 
Table A3. Within County Difference-In-Means ESTIMATES

\begin{tabular}{|c|c|c|c|}
\hline \multicolumn{4}{|l|}{ Balance Tests } \\
\hline Bandwidth (b): & 50 & 75 & 100 \\
\hline $251-\mathrm{b} \leq$ Approx. Reg. $\leq 250$ & 297 & 500 & 704 \\
\hline $251 \leq$ Approx. Reg. $\leq 250+$ b & 168 & 290 & 418 \\
\hline$\%$ Mail Ballots & $\begin{array}{c}0.275 \\
(0.017)\end{array}$ & $\begin{array}{c}0.325 \\
(0.013)\end{array}$ & $\begin{array}{c}0.360 \\
(0.010)\end{array}$ \\
\hline$\%$ Rural & $\begin{array}{c}\mathbf{0 . 0 8 7} \\
(\mathbf{0 . 0 3 3})\end{array}$ & $\begin{array}{c}0.083 \\
(0.026)\end{array}$ & $\begin{array}{c}0.101 \\
(\mathbf{0 . 0 2 2})\end{array}$ \\
\hline$\%$ White & $\begin{array}{c}0.057 \\
(\mathbf{0 . 0 1 9})\end{array}$ & $\begin{array}{c}0.053 \\
(0.015)\end{array}$ & $\begin{array}{r}0.048 \\
(0.013)\end{array}$ \\
\hline$\%$ Black & $\begin{array}{c}-0.007 \\
(0.005)\end{array}$ & $\begin{array}{l}-0.008 \\
(0.004)\end{array}$ & $\begin{array}{l}-0.005 \\
(0.004)\end{array}$ \\
\hline$\%$ Asian & $\begin{array}{r}-0.026 \\
(0.013)\end{array}$ & $\begin{array}{r}-0.035 \\
(0.011)\end{array}$ & $\begin{array}{l}-0.033 \\
(0.009)\end{array}$ \\
\hline \% Hispanic & $\begin{array}{l}-0.024 \\
(0.011)\end{array}$ & $\begin{array}{r}-0.014 \\
(0.009)\end{array}$ & $\begin{array}{l}-0.012 \\
(0.008)\end{array}$ \\
\hline$\%$ Age $18-29$ & $\begin{array}{l}-0.006 \\
(0.009)\end{array}$ & $\begin{array}{l}-0.012 \\
(0.008)\end{array}$ & $\begin{array}{l}-0.014 \\
(0.007)\end{array}$ \\
\hline$\%$ Age $30-44$ & $\begin{array}{c}-0.025 \\
(0.008)\end{array}$ & $\begin{array}{r}-0.016 \\
(0.006)\end{array}$ & $\begin{array}{l}-0.015 \\
(0.005)\end{array}$ \\
\hline$\%$ Age $45-64$ & $\begin{array}{c}0.005 \\
(0.009)\end{array}$ & $\begin{array}{c}0.017 \\
(\mathbf{0 . 0 0 7})\end{array}$ & $\begin{array}{c}0.022 \\
(0.006)\end{array}$ \\
\hline$\%$ Age $65+$ & $\begin{array}{c}0.025 \\
(0.012)\end{array}$ & $\begin{array}{c}0.011 \\
(0.010)\end{array}$ & $\begin{array}{c}0.006 \\
(0.008)\end{array}$ \\
\hline$\%$ Democrat & $\begin{array}{c}-\mathbf{0 . 0 2 2} \\
(\mathbf{0 . 0 1 1})\end{array}$ & $\begin{array}{c}-0.014 \\
(0.008)\end{array}$ & $\begin{array}{c}-0.017 \\
(\mathbf{0 . 0 0 7})\end{array}$ \\
\hline$\%$ Republican & $\begin{array}{c}0.034 \\
(\mathbf{0 . 0 1 2})\end{array}$ & $\begin{array}{c}\text { 0.028 } \\
(\mathbf{0 . 0 1 0})\end{array}$ & $\begin{array}{c}\text { 0.030 } \\
(\mathbf{0 . 0 0 8})\end{array}$ \\
\hline$\%$ Decline to State & $\begin{array}{r}-0.012 \\
(0.005)\end{array}$ & $\begin{array}{r}-0.014 \\
(\mathbf{0 . 0 0 5 )}\end{array}$ & $\begin{array}{r}-0.014 \\
(0.004)\end{array}$ \\
\hline$\%$ Minor Party & $\begin{array}{c}0.000 \\
(0.002)\end{array}$ & $\begin{array}{c}0.000 \\
(0.002)\end{array}$ & $\begin{array}{c}0.001 \\
(0.001)\end{array}$ \\
\hline$\%$ Male & $\begin{array}{c}0.002 \\
(0.004)\end{array}$ & $\begin{array}{c}0.000 \\
(0.003)\end{array}$ & $\begin{array}{r}-0.001 \\
(0.003)\end{array}$ \\
\hline$\%$ Female & $\begin{array}{c}-0.003 \\
(0.004)\end{array}$ & $\begin{array}{r}-0.007 \\
(\mathbf{0 . 0 0 3})\end{array}$ & $\begin{array}{r}-0.007 \\
(0.003)\end{array}$ \\
\hline \% Unknown Gender & $\begin{array}{c}0.001 \\
(0.005)\end{array}$ & $\begin{array}{c}0.007 \\
(0.004)\end{array}$ & $\begin{array}{c}0.008 \\
(0.004)\end{array}$ \\
\hline$\%$ Late Registrants & $\begin{array}{c}0.002 \\
(0.003)\end{array}$ & $\begin{array}{c}-0.002 \\
(0.002)\end{array}$ & $\begin{array}{r}-0.004 \\
(0.002)\end{array}$ \\
\hline $\begin{array}{l}\text { \% Absentee } \\
\text { (Santa Clara Only) }\end{array}$ & $\begin{array}{c}0.012 \\
(0.005)\end{array}$ & $\begin{array}{c}0.012 \\
(0.005)\end{array}$ & $\begin{array}{c}\text { 0.012 } \\
(\mathbf{0 . 0 0 5})\end{array}$ \\
\hline
\end{tabular}

TABle A3. Continued

Democratic Primary

\begin{tabular}{|c|c|c|c|}
\hline $\begin{array}{l}\text { Bandwidth (b): } \\
251-\text { b } \leq \text { Approx. Reg. } \leq 250 \\
251 \leq \text { Approx. Reg. } \leq 250+b\end{array}$ & $\begin{array}{c}50 \\
297 \\
168\end{array}$ & $\begin{array}{c}75 \\
500 \\
290\end{array}$ & $\begin{array}{l}100 \\
704 \\
418\end{array}$ \\
\hline $\begin{array}{l}\text { First Stage } \\
\% \text { Mail Ballots }\end{array}$ & $\begin{array}{c}0.310 \\
(0.018)\end{array}$ & $\begin{array}{c}\mathbf{0 . 3 5 9} \\
(\mathbf{0 . 0 1 3})\end{array}$ & $\begin{array}{r}0.394 \\
(0.011)\end{array}$ \\
\hline $\begin{array}{l}\text { Second Stage } \\
\% \text { Obama-\% Clinton } \\
\% \text { Edwards } \\
\text { Republican Primary }\end{array}$ & $\begin{array}{c}-0.022 \\
(0.072) \\
\mathbf{0 . 0 4 3} \\
(\mathbf{0 . 0 1 2})\end{array}$ & $\begin{array}{c}-0.058 \\
(0.051) \\
\mathbf{0 . 0 3 9} \\
(\mathbf{0 . 0 0 8})\end{array}$ & $\begin{array}{c}-0.042 \\
(0.041) \\
\mathbf{0 . 0 4 6} \\
(\mathbf{0 . 0 0 7 )}\end{array}$ \\
\hline $\begin{array}{l}\text { Bandwidth }(b) \text { : } \\
251-b \leq \text { Forcing } \leq 250 \\
251 \leq \text { Forcing } \leq 250+b\end{array}$ & $\begin{array}{c}50 \\
297 \\
167\end{array}$ & $\begin{array}{c}75 \\
500 \\
289\end{array}$ & $\begin{array}{l}100 \\
703 \\
416\end{array}$ \\
\hline $\begin{array}{l}\text { First Stage } \\
\% \text { Mail Ballots }\end{array}$ & $\begin{array}{c}0.317 \\
(\mathbf{0 . 0 2 6})\end{array}$ & $\begin{array}{c}0.358 \\
(0.019)\end{array}$ & $\begin{array}{c}0.390 \\
(0.016)\end{array}$ \\
\hline $\begin{array}{l}\text { Second Stage } \\
\% \text { Huckabee - \% McCain }\end{array}$ & $\begin{array}{c}0.026 \\
(0.058)\end{array}$ & $\begin{array}{c}0.037 \\
(0.037)\end{array}$ & $\begin{array}{l}0.060 \\
(0.028)\end{array}$ \\
\hline \% Huckabee - \% Romney & $\begin{array}{l}0.015 \\
(0.055)\end{array}$ & $\begin{array}{c}0.023 \\
(0.034)\end{array}$ & $\begin{array}{c}0.033 \\
(0.026)\end{array}$ \\
\hline \% Romney - \% McCain & $\begin{array}{c}0.011 \\
(0.069)\end{array}$ & $\begin{array}{c}0.014 \\
(0.045)\end{array}$ & $\begin{array}{c}0.027 \\
(0.034)\end{array}$ \\
\hline$\%$ Giuliani & $\begin{array}{c}0.032 \\
(0.016)\end{array}$ & $\begin{array}{c}0.029 \\
(0.010)\end{array}$ & $\begin{array}{c}0.032 \\
(0.008)\end{array}$ \\
\hline$\%$ Thompson & $\begin{array}{c}0.013 \\
(0.012)\end{array}$ & $\begin{array}{l}0.017 \\
(0.008)\end{array}$ & $\begin{array}{c}0.020 \\
(0.006)\end{array}$ \\
\hline
\end{tabular}

Standard errors in parenthesis. Bold indicates a significant difference at $95 \%$ level. 
Table A4. Balance Tests FOR RDD-BASED ESTIMATOR

\begin{tabular}{|c|c|c|c|}
\hline Bandwidth (b) & $\begin{array}{l}(1) \\
50\end{array}$ & $\begin{array}{l}(2) \\
75\end{array}$ & $\begin{array}{l}(3) \\
100\end{array}$ \\
\hline $251-\mathrm{b} \leq$ Approx. Reg. $\leq 250$ & 271 & 456 & 633 \\
\hline $251 \leq$ Approx. Reg. $\leq 250+$ b & 157 & 262 & 369 \\
\hline $250+\mathrm{b}<$ Approx. Reg. & 1,019 & 1,485 & 1,863 \\
\hline$\%$ Mail Ballots & $\begin{array}{c}0.261 \\
(0.015)\end{array}$ & $\begin{array}{c}0.310 \\
(0.011)\end{array}$ & $\begin{array}{r}0.346 \\
(0.009)\end{array}$ \\
\hline$\%$ Rural & $\begin{array}{c}0.050 \\
(0.036)\end{array}$ & $\begin{array}{c}0.026 \\
(0.029)\end{array}$ & $\begin{array}{r}0.023 \\
(0.024)\end{array}$ \\
\hline$\%$ White & $\begin{array}{c}-0.004 \\
(0.014)\end{array}$ & $\begin{array}{c}0.004 \\
(0.011)\end{array}$ & $\begin{array}{r}0.000 \\
(0.009)\end{array}$ \\
\hline$\%$ Black & $\begin{array}{c}-0.001 \\
(0.007)\end{array}$ & $\begin{array}{c}-0.003 \\
(0.005)\end{array}$ & $\begin{array}{r}-0.001 \\
(0.004)\end{array}$ \\
\hline$\%$ Asian & $\begin{array}{r}-0.010 \\
(0.008)\end{array}$ & $\begin{array}{r}-0.010 \\
(0.007)\end{array}$ & $\begin{array}{r}-0.009 \\
(0.005)\end{array}$ \\
\hline$\%$ Hispanic & $\begin{array}{c}0.011 \\
(0.008)\end{array}$ & $\begin{array}{c}0.003 \\
(0.007)\end{array}$ & $\begin{array}{r}0.006 \\
(0.006)\end{array}$ \\
\hline$\%$ Age $18-29$ & $\begin{array}{c}0.001 \\
(0.008)\end{array}$ & $\begin{array}{r}-0.005 \\
(0.007)\end{array}$ & $\begin{array}{r}-0.005 \\
(0.006)\end{array}$ \\
\hline$\%$ Age $30-44$ & $\begin{array}{r}-0.020 \\
(0.011)\end{array}$ & $\begin{array}{r}-0.014 \\
(0.009)\end{array}$ & $\begin{array}{r}-0.012 \\
(0.007)\end{array}$ \\
\hline$\%$ Age $45-64$ & $\begin{array}{r}-0.005 \\
(0.009)\end{array}$ & $\begin{array}{c}0.011 \\
(0.007)\end{array}$ & $\begin{array}{r}0.013 \\
(0.006)\end{array}$ \\
\hline$\%$ Age $65+$ & $\begin{array}{c}0.024 \\
(0.016)\end{array}$ & $\begin{array}{c}0.007 \\
(0.012)\end{array}$ & $\begin{array}{r}0.004 \\
(0.010)\end{array}$ \\
\hline$\%$ Democratic & $\begin{array}{r}-0.003 \\
(0.008)\end{array}$ & $\begin{array}{r}-0.001 \\
(0.007)\end{array}$ & $\begin{array}{r}-0.002 \\
(0.006)\end{array}$ \\
\hline$\%$ Republican & $\begin{array}{c}0.012 \\
(0.010)\end{array}$ & $\begin{array}{c}0.010 \\
(0.008)\end{array}$ & $\begin{array}{r}0.010 \\
(0.007)\end{array}$ \\
\hline$\%$ Decline to State & $\begin{array}{r}-0.010 \\
(\mathbf{0 . 0 0 5})\end{array}$ & $\begin{array}{r}-0.010 \\
(0.004)\end{array}$ & $\begin{array}{r}-0.008 \\
(0.004)\end{array}$ \\
\hline$\%$ Minor Party & $\begin{array}{c}0.001 \\
(0.002)\end{array}$ & $\begin{array}{c}0.001 \\
(0.002)\end{array}$ & $\begin{array}{r}0.001 \\
(0.001)\end{array}$ \\
\hline$\%$ Male & $\begin{array}{c}0.001 \\
(0.005)\end{array}$ & $\begin{array}{c}0.001 \\
(0.004)\end{array}$ & $\begin{array}{r}0.002 \\
(0.003)\end{array}$ \\
\hline$\%$ Female & $\begin{array}{r}-0.008 \\
(0.005)\end{array}$ & $\begin{array}{r}-0.009 \\
(0.004)\end{array}$ & $\begin{array}{r}-0.008 \\
(0.003)\end{array}$ \\
\hline$\%$ Unknown Gender & $\begin{array}{c}0.007 \\
(0.007)\end{array}$ & $\begin{array}{c}0.008 \\
(0.005)\end{array}$ & $\begin{array}{r}0.006 \\
(0.005)\end{array}$ \\
\hline$\%$ Late Registrants & $\begin{array}{c}0.000 \\
(0.003)\end{array}$ & $\begin{array}{c}-0.001 \\
(0.002)\end{array}$ & $\begin{array}{r}-0.003 \\
(0.002)\end{array}$ \\
\hline $\begin{array}{l}\% \text { Absentee } \\
\text { (Santa Clara Only) }\end{array}$ & $\begin{array}{c}0.006 \\
(0.008)\end{array}$ & $\begin{array}{c}0.001 \\
(0.006)\end{array}$ & $\begin{array}{r}0.004 \\
(0.006)\end{array}$ \\
\hline
\end{tabular}

Standard errors in parenthesis. Bold indicates a significant difference at 95\% level. 
